HYDROGEOLOGY AND LEACHATE MOVEMENT NEAR TWO CHEMICAL-WASTE SITES

IN OSWEGO COUNTY, NEW YORK

By Henry R. Anderson and Todd S. Miller

U.S. GEOLOGICAL SURVEY

Water-Resources Investigations Report 84-4148

Prepared in cooperation with

OSWEGO COUNTY

Ithac a, New York

1986 
UNITED STATES DEPARTMENT OF THE INTERIOR

DONALD PAUL HODEL, Secretary

GEOLOGICAL SURVEY

Dallas L. Peck, Director

For additional information write to:

U.S. Geological Survey

$521 \mathrm{~W}$. Seneca Street

Ithaca, New York 14850

(607) 272-8722
Copies of this report may be purchased from:

Open-File Services Section Western Distribution Branch

U.S. Geological Survey Box 25425, Federal Center Denver, Colo. 80225

(303) 236-7476 


\section{CONTENTS}

Abstract. .............................

Introduction. . . . . . . . . . . . . . . . . .

Purpose and scope........................

Previous work . . . . . . . . . . . . . . . . . .

Methods... . . . . . . . . . . . . . . . .

Acknowledgments . . . . . . . . . . . . . . . . .

Regional hydrogeology . . . . . . . . . . . . . . . . .

Bedrock . . . . . . . . . . . . . . . . . . . . .

Unconsolidated deposits . . . . . . . . . . . . . . .

Lodgment till. . . . . . . . . . . . . . . . . .

Ablation till. . . . . . . . . . . . . . . . . .

Lake deposits. . . . . . . . . . . . . . . . . . .

Sand and gravel......................... .

Ground-water conditions and leachate movement at site near 0swego . .

Hydrogeology and ground-water conditions. . . . . . . . . .

Permeability . . . . . . . . . . . . . . . . . . . . . .

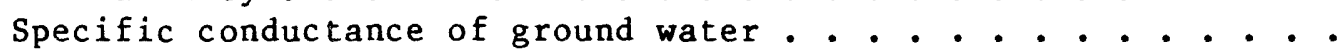

Chemical quality. . . . . . . . . . . . . . . . . . . .

Halogens. . . . . . . . . . . . . . . . . . . . .

Trace metals. . . . . . . . . . . . . . . . . . . .

Organic compounds . . . . . . . . . . . . . . . . . .

Movement of leachate . . . . . . . . . . . . . . . . . .

Ground-water conditions and leachate movement at landfill near Fulton.

Hydrogeology and ground-water conditions. . . . . . . . . .

Permeability . . . . . . . . . . . . . . . . . . . . . . .

Specific conductance . . . . . . . . . . . . . . . . . . . .

Temperature. . . . . . . . . . . . . . . . . . . . . . .

Chemical quality . . . . . . . . . . . . . . . . . . . .

Halogens. . . . . . . . . . . . . . . . . . . .

Trace metals. . . . . . . . . . . . . . . . . .

Organic compounds . . . . . . . . . . . . . . . . . .

Movement of leachate . . . . . . . . . . . . . . . . .

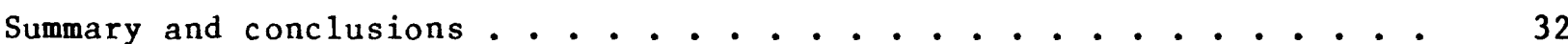

Site near Oswego. . . . . . . . . . . . . . . . . . . . 32

Landfill near Fulton. . . . . . . . . . . . . . . . . . . . 33

Selected references . . . . . . . . . . . . . . . . . . . . . 34

\section{ILLUSTRATIONS}

Figure 1.--Map showing location of chemical-waste disposal sites in relation to sand and gravel deposits in Oswego County. . .

2-3.--Geologic maps of Oswego County showing:

2.--Bedrock geology. . . . . . . . . . . . . .

3.--Surficial geology. . . . . . . . . . . . . 


\section{ILLUSTRATIONS (continued)}

Page

Figure 4.--Map showing surficial geology, location of observation wells and test holes, and 1980 water-table contours in vicinity of chemical-waste-disposal site near 0swego. . .

5.--Geologic section $A-A^{\prime}$ through vicinity of chemicalwaste-disposal site near Oswego . . . . . . . . . .

6-8.--Maps of chemical-waste-disposal site near 0swego showing:

6.--Specific conductance of ground water, August 1980 ...

7.--Concentration of lead, mercury, and arsenic in ground water, August 1980 . . . . . . . . .

8.--Concentration of selected organic compounds in ground water, August 1980 ............

9.--Map of surficial geology, location of observation wells and test holes, and water-table contours in vicinity of landfill near Fulton, 1980 . . . . . . . . . . . . . .

10.--Map showing saturated thickness of sand and of sand and gravel aquifer in vicinity of landfill near Fulton. . . .

11.--Geologic sections in vicinity of landfill near Fulton:

$A-A^{\prime}$ along Silk Road. . . . . . . . . . . . .

B-B' along Howard Road. ................ 22

C-C' south of landfill near Fulton. . . . . . . . . . 23

12.--Maps showing specific conductance of ground water in vicinity of landfill near Fulton:

A. May 1980 . . . . . . . . . . . . . . 24

B. February 1981......................... 25

13.--Maps showing temperature of ground water in vicinity of landfill near Fulton:

A. May 1980 . . . . . . . . . . . . . . . 27

B. November 1980................. . . . . 28

C. February 1981................... 29

\section{TABLES}

Table 1.--Chemical compounds received at chemical-waste site near Oswego, 1969. . . . . . . . . . . . . . .

2.--Results of permeability tests at chemical waste-disposal site near 0swego. . . . . . . . . . . . . . . 


\section{TABLES (continued)}

Table 3.--Concentrations of selected halogens and trace metals in water from observation wells at the chemical waste-disposal facility near Oswego . . . . . . . . . . . . . .

4. Chemical analyses for selected "priority" organic compounds in ground water from vicinity of chemical waste-disposal site near Oswego, August 1980 . . . . . . . . . . . . .

5. Volatile organic "priority pollutants" tested for but not detected in ground-water samples from vicinity of chemicalwaste-disposal site near 0swego. . . . . . . . . . .

6. Concentrations of trace metals and halogens in ground water in vicinity of landfill near fulton. . . . . . . .

7. Concentrations of selected "priority" organic compounds in ground water in vicinity of landfill near Fulton. . . .

8. Records of selected wells and test holes at the chemicalwaste-disposal site near 0swego. . . . . . . . . . .

9. Records of selected wells and test holes at the landfill near fulton. . . . . . . . . . . . . . . . .

\section{CONVERSION FACTORS AND ABBREVIATIONS}

Factors for converting the inch-pound units used in this report to International system of units (SI) are shown below.

Multiply Inch-Pound Unit

foot ( $f t)$

yard (yd)

mile (mi)

acre

square mile (mi2)

gallon per minute (gal/min)

million gallons per day (Mgal/d)

foot per mile ( $\mathrm{ft} / \mathrm{mi}$ )

gallon per day (gal/d)

foot per day ( $f t / d$ )

foot squared per day ( $f t 2 / d$ )

degrees Fahrenheit $\left({ }^{\circ} \mathrm{F}\right)$

\section{By}

0.3048

0.914

1.609

0.004

2.590

0.0038

3785 .

0.1894

0.0038

0.3048

0.0929

$1.8^{\circ} \mathrm{C}+32$
To Obtain SI Unit

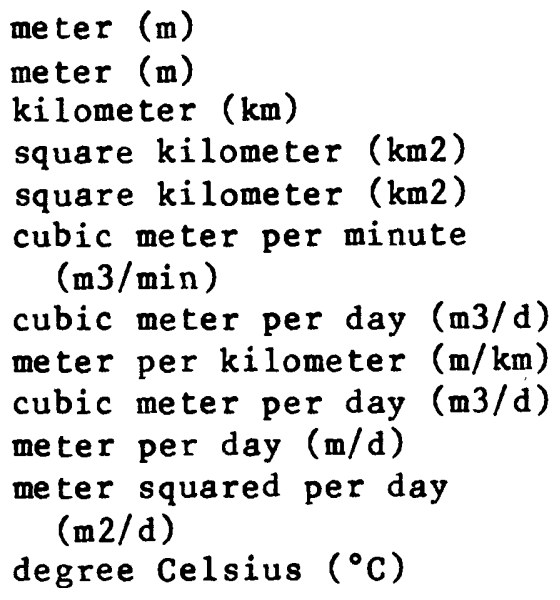

\section{Other Abbreviations}

micrograms per liter ()g/L) milligram per liter (mg/L) 


\title{
HYDROGEOLOGY AND LEACHATE MOVEMENT NEAR TWO CHEMICAL-WASTE SITES IN OSWEGO COUNTY, NEW YORK
}

\author{
by
}

Henry R. Anderson and Todd S. Miller

\begin{abstract}
Forty-five observation wells and test holes were installed at two chemical-waste-disposal sites in Oswego County to evaluate the hydrogeologic conditions and the rate and direction of leachate migration.

At the site near Oswego, ground water moves northward at an average velocity of 0.4 feet per day ( $\mathrm{ft} / \mathrm{d}$ ) through unconsolidated glacial deposits 10 to $40 \mathrm{ft}$ thick and discharges into White Creek and Wine Creek, which border the site and discharge to Lake Ontario. Leaking barrels of chemical wastes have contaminated the ground water within the site, as evidenced by detection of nine "priority pollutant" organic compounds and elevated levels of specific conductance, chloride, and some trace metals (arsenic, lead, and mercury) at wells inside the site but not at wells upgradient or beyond the streams.

At the site near Fulton, a sanitary landfill in which 8,000 barrels of chemical wastes were buried, ground water in the sand and in the sand and gravel aquifer that borders the landfill to the south and east moves southward and eastward at an average velocity of $2.8 \mathrm{ft} / \mathrm{d}$ and discharges to Bell Creek (which discharges to the Oswego River) or moves southward beneath the creek. Leachate is migrating to the east, southeast, and southwest of the landfill, as evidenced by elevated values of specific conductance, temperature, and several trace metals in water at wells in these areas.
\end{abstract}

\section{INTRODUCTION}

Large quantities of toxic chemicals were buried or temporarily stored at nine or more sites within 0swego County during 1968-77. The largest known amount of stored chemical waste is at a 46-acre waste-incinerator facility at the eastern edge of the City of 0 swego, $1 / 2 \mathrm{mi}$ south of Lake Ontario (fig. 1). The site began operation in 1969 and, during the next 9 years, incinerated monthly about 1 Mgal of liquid chemical acids, bases, nonchlorinated organic solvents, and organic solids (Scrudato and others, 1980).

In 1974, a chemical spill at the site caused chemicals to overflow from a storage lagoon, flood the site, and flow $1 / 2 \mathrm{mile}$ north to Lake ontario. This event, combined with earlier violations of local, State, and Federal regulations, resulted in condemnation of the site. In August 1977, the owners abandoned the facility. Approximately 11,000 fifty-five gallons drums of chemical waste remain stockpiled at the site. 
The waste-incinerator facility was equipped to handle liquid waste only. In 1974, approximately 8,000 fifty-five-gallon barrels containing solid waste were transported from the 0 swego site and buried at a 70-acre county sanitary landfill near the City of Fulton, 10 miles southwest of the main site (fig. 1 ). Another 9,000 barrels of chemical waste are at seven other locations in the county.

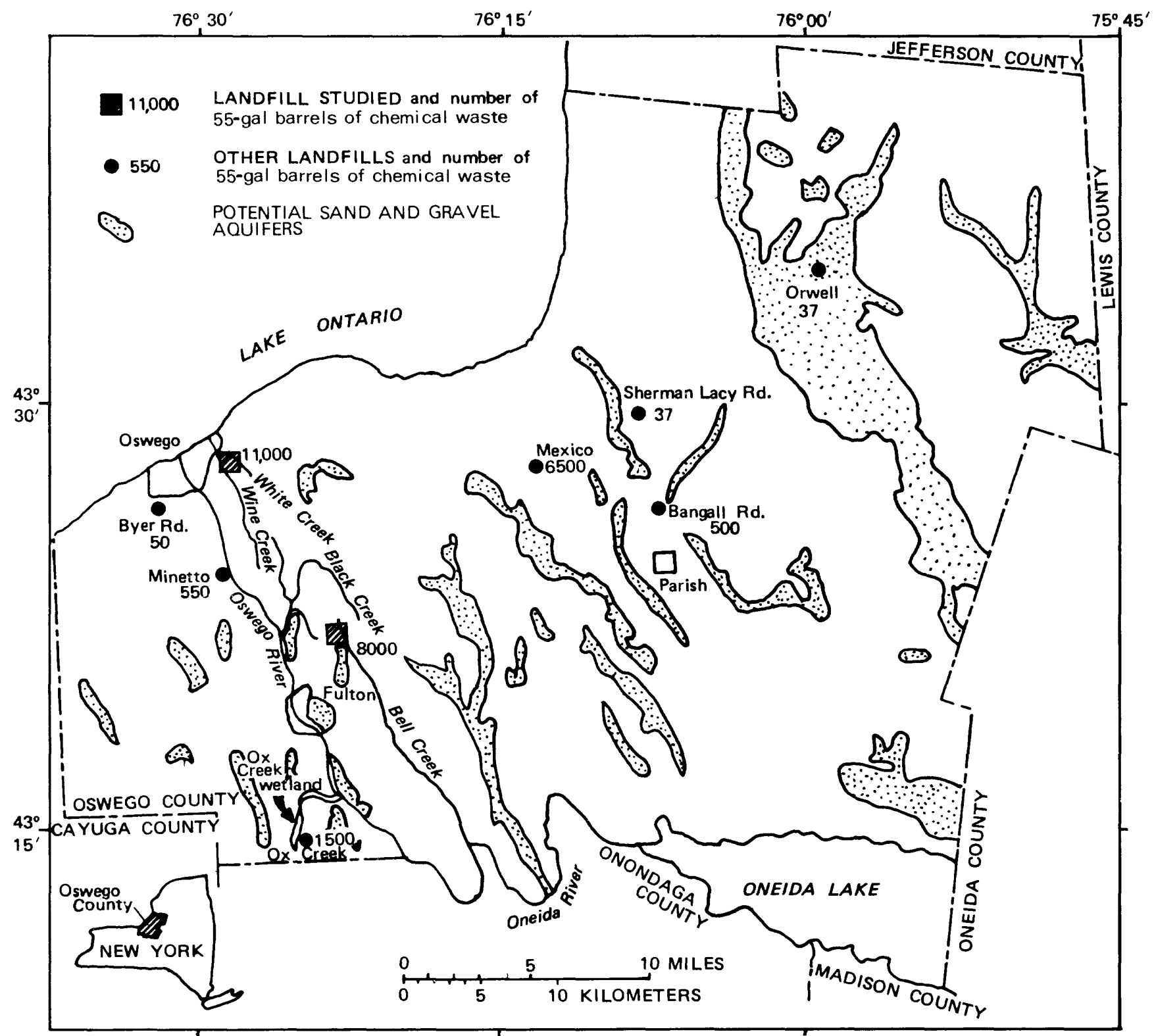

Base from U.S. Geological Survey

State base map 1:500,000,1974

Figure 1.--Location of chemical-waste-disposal sites in relation to sand and gravel deposits in Oswego County. (Modified from Milzer, 1982.) 
The 28,000 barrels of chemical waste at the nine sites in the county present a threat to the county's water resources and also pose a potential health hazard. Approximately 70 percent of the county's population obtains drinking water from ground-water resources, and the remaining 30 percent from Lake Ontario, to which all water in the county flows.

The U.S. Geological Survey, in cooperation with Oswego County and the State University Research Center at Oswego (SURCO), studied hydrologic conditions and leachate movement at the two disposal sites during 1979-1981.

\section{Purpose and Scope}

This report evaluates the potential for contaminant migration from the 19,000 barrels of chemical waste at the two largest chemical-waste-disposal sites in the county. It also presents tables of chemical analyses and a series of maps illustrating the extent of leachate migration from the sites. Maps and cross sections showing geology, temperature, and specific conductance of ground water, and the water-table altitude at the two sites, are included for reference. Suggestions for further sampling at the two sites also are given.

\section{Previous Work}

Miller (1980, 1981) mapped and described the surficial geology of this part of Oswego County and indicated the location of the county's major permeable deposits. Scrudato and others (1980) presented a historical review of the waste sites and compiled an inventory of the number of barrels and types of chemical wastes.

\section{Methods}

The U.S. Geological Survey mapped the major aquifers, documented the direction and estimated rate of ground-water movement, and measured specific conductance and temperture of ground water. SURCO sampled the ground water and described its chemical character.

A total of 45 test holes and wells were installed, 21 at the wasteincinerator facility near Oswego and 24 at the landfill near Fulton, to obtain hydrogeologic and water-quality information needed to compile maps showing direction of ground-water flow and the extent of leachate migration. At least one well was installed upgradient of each site to evaluate background water quality. Well screens were installed in the most permeable unit encountered during drilling (usually sand, gravel, or artifical fill) because these deposits would be the ready avenues of contaminant migration. If a permeable unit was thick or occurred as several interbedded layers, a set of nested wells was installed at differing depths to detect the vertical extent of contamination.

The basal confining unit at both sites is a till consisting of a very fine sandy, clayey silt matrix with embedded pebbles and cobbles. Wells had a 1-1/4-inch or 2-inch inside diameter and ranged from 5 to $80 \mathrm{ft}$ deep. At most drill sites, a steel well was installed for sampling organic and inorganic compounds, but at some, a polyvinylchloride well was installed for sampling inorganic compounds. 
Ground-water samples were collected at 14 wells ( 7 at each site) and sent to the U.S. Geological Survey laboratory in Atlanta, Ga., for analysis. Five samples from each site were analyzed for 28 of the 129 "priority pollutants" (Keith and Telliard, 1979) of the U.S. Environmental Protection Agency, and two other samples from both sites were analyzed for several trace metals and two for halogens. Sampling locations were chosen to provide data on ground water both upgradient and downgradient of the waste sites. Specific conductance and temperature were measured quarterly to document seasonal variations and to serve as indicators of leachate migration.

Before sample collection, at least three volumes of water in the well casing were removed to ensure that the water sampled was from the aquifer and not water that had been standing in the casing. A peristalic pump with Tygonl tubing was used to pump the wells and collect the samples.

\section{Acknowledgments}

The project was done with the assistance of of Dr. Ronald Scrudato of the State University Research Center (SURCO) at Oswego, N.Y. SURCO was instrumental in planning and organizing the project and assisted in obtaining equipment and collecting and analyzing water samples.

\section{REGIONAL HYDROGEOLOGY}

\section{Bedrock}

Bedrock in Oswego County is almost entirely covered by glacial deposits but is exposed locally in some stream channels and quarries. Distribution of the major units in Oswego County is depicted in figure 2. The area studied is underlain by sedimentary-rock units of Ordovician and Silurian age. The Oswego Sandstone crops out beneath the waste-incinerator facility site near Oswego; the Queenston Formation and Medina Sandstone Group crops out beneath the landfill near Fulton (fig. 2).

Bedrock typically yields larger quantities of ground water than till, clay, or silt, but lesser quantities than sand and gravel. Although the intergranular pore spaces are mostly filled with cement, fracturing increases effective porosity to approximately 5 percent. Where water is confined under artesian pressure, water levels in wells tapping bedrock may rise above the land surface. The median yield of drilled wells tapping the local sandstone is $10 \mathrm{gal} / \mathrm{min}$ and ranges locally from 0.5 to $125 \mathrm{gal} / \mathrm{min}$ (Kantrowitz, 1970).

On a regional basis, ground water in the bedrock flows northward, against southward dip of the beds, and discharges into Lake Ontario (Kantrowitz, 1970). In recharge areas south of Lake Ontario, ground water flows downward, dissolving salts from deeper marine deposits, and becomes mixed with entrapped brackish water and brine. Thus, ground water below $100 \mathrm{ft}$ in depth in Oswego County generally is brackish.

1 Use of brand names is for indentification only and does not imply endorsement by the U.S. Geological Survey. 


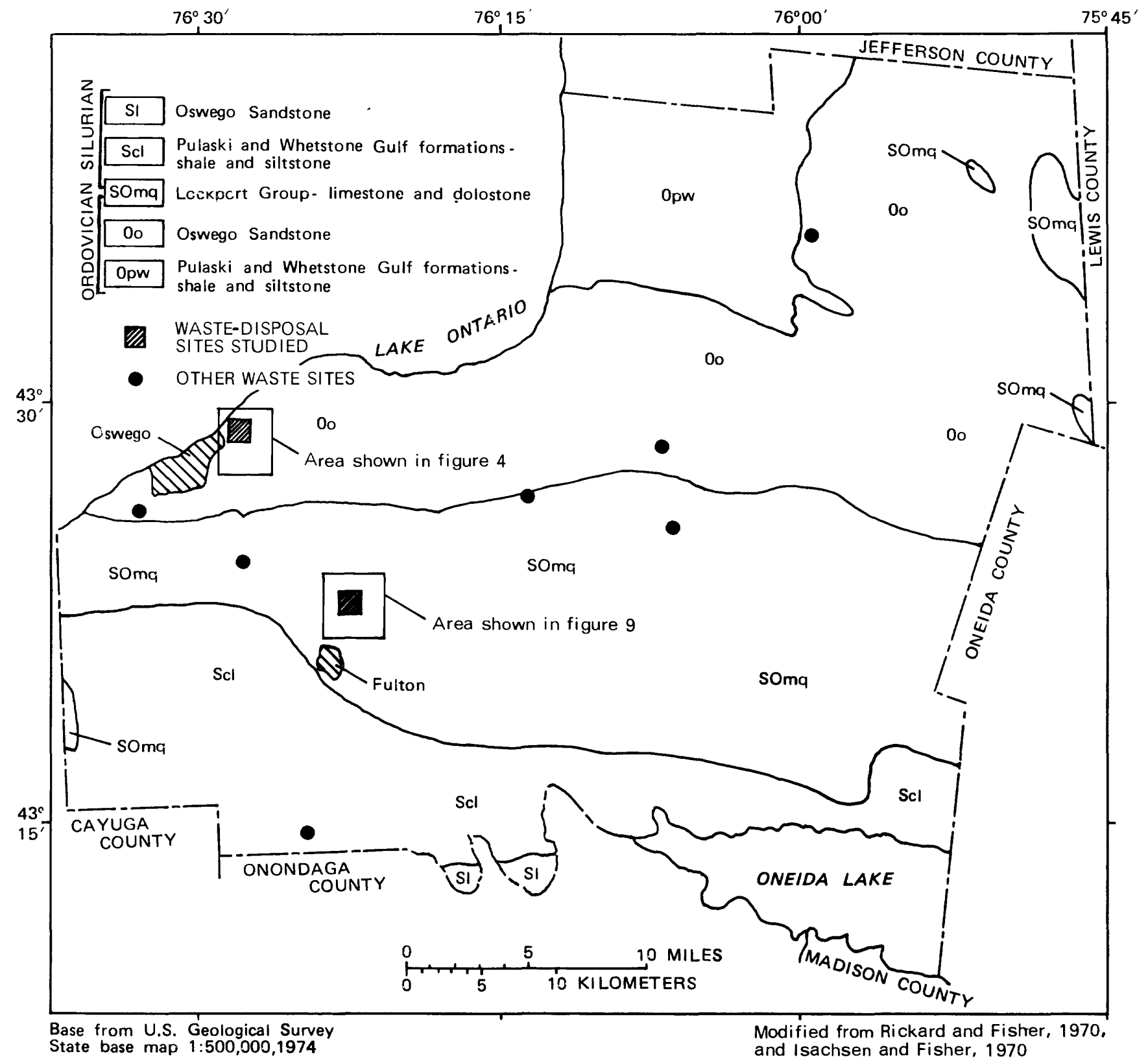

Figure 2.--Bedrock geology of Oswego County. (Modified from Isachsen and Fisher, 1970.)

\section{Unconsolldated Deposits}

The unconsolidated materials overlying bedrock in Oswego County consist of glacial and swamp deposits. The two chemical-waste sites studied are within a drumlin field that covers much of north-central New York. The lower flanks of drumlins and the interdrumlin areas are overlain with relatively impermeable lake deposits consisting of fine sand, silt, and clay. Sporadic patches of 
ablation till and sand and gravel, deposited as kames or by glacial-lake wave action, are present throughout the drumlin field. Some of these sand and gravel deposits are potential ground-water sources. The distribution of surficial unconsolidated deposits is shown in figure 3 ; the location of the chemical-waste sites in relation to sand and gravel deposits is depicted in figure 1 .

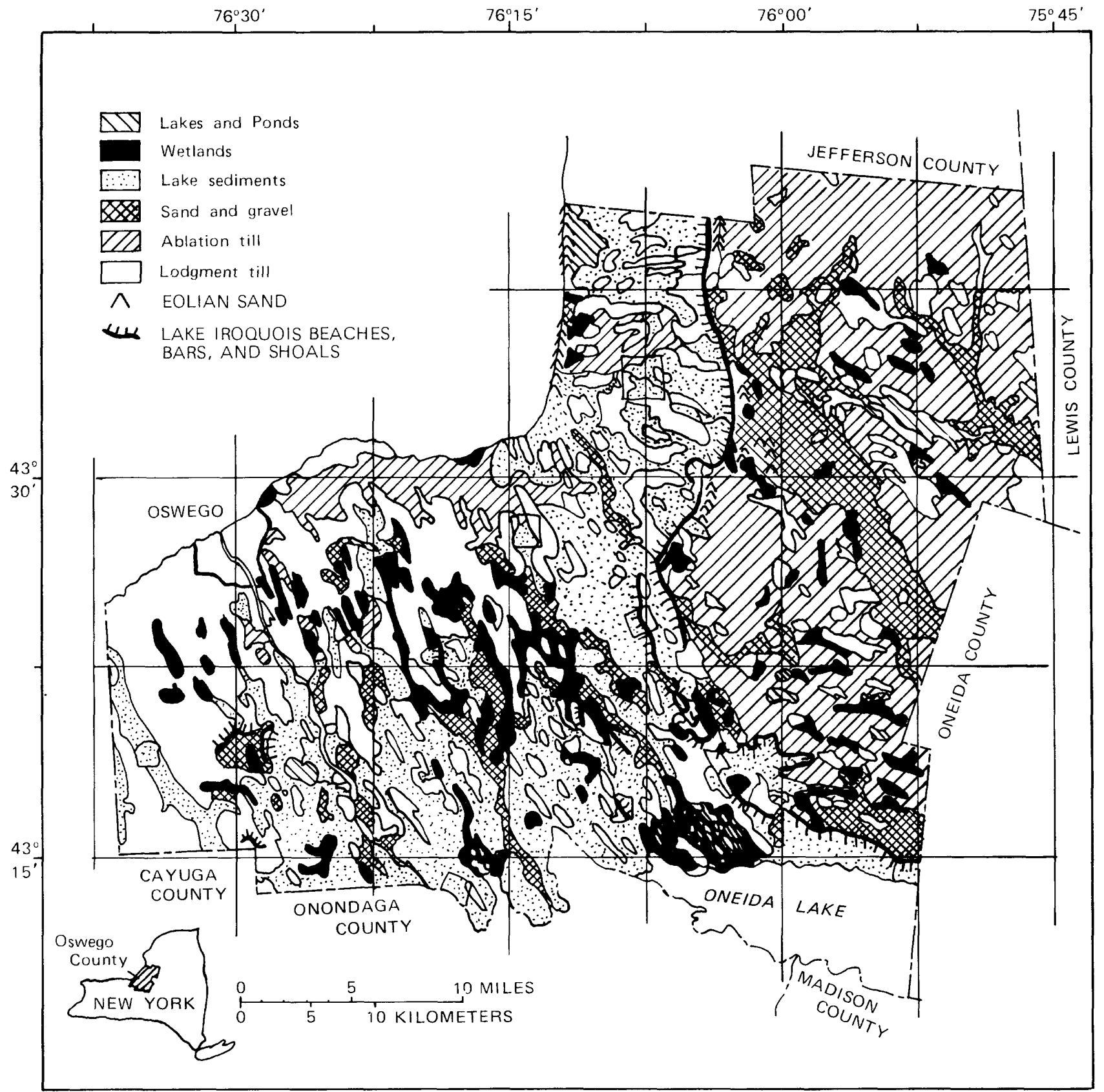




\section{Lodgment Tizz}

Lodgment till is a poorly sorted, dense, clay to boulder material compacted upon the bedrock surface by glaciers. In the vicinity of the chemicalwaste sites studied, lodgment till forms elliptical, streamlined hills called drumlins that are aligned parallel to the direction of glacier movement and range in thickness from $5 \mathrm{ft}$ to more than $150 \mathrm{ft}$. Lodgment till in some areas is covered by more permeable deposits, including ablation till or sand and gravel. The lower flanks of drumlins and interdrumlin areas are commonly covered with lake or swamp deposits.

Lodgment till is relatively impermeable and is therefore a poor aquifer; however, it yields sufficient water for domestic and small-farm use through large-diameter dug wells.

\section{Ablation Tizl}

Ablation till was deposited by stagnant melting glaciers as loosely unconsolidated clay, silt, and large boulders. It forms irregular knobby hills that parallel former glacier margins and typically overlies lodgment till or bedrock. Ablation till is coarser, less consolidated, and slightly more permeable than lodgment till but less permeable than sand or gravel.

\section{Lake Deposits}

Lake sediments consisting of relatively impermeable very fine sand, silt, and clay were deposited in an ice-impounded lake (Lake Iroquois) that inundated most of western and central Oswego County. Most deposits are less than $50 \mathrm{ft}$ thick and occur mostly along the lower flanks of drumlins, within interdrumlin areas, and offshore from former beaches. Lake deposits of well-sorted fine sand have moderate aquifer potential.

\section{Sand and Gravel}

Stratified sand and gravel deposits are the most productive aquifers in Oswego County. They were deposited by glacial meltwater in fast-moving streams and by wave action that formed beaches of glacial lakes. Most sand and gravel deposits overlie lodgment till, but in the interdrumlin areas they may be buried beneath lake deposits. Sand and gravel deposits in central and western Oswego County typically cover less than $1 \mathrm{mi}^{2}$ and are less than $80 \mathrm{ft}$ thick.

Sand and gravel is highly permeable and porous. Where deposits are at land surface, the ground water may be unconfined, but where the deposits are buried beneath lacustrine silt and clay, the ground water may be confined and under artesian pressure. Porosity ranges from 25 to 50 percent. Well yields from these deposits are controlled by the size of the recharge area and the recharge rate. Yields are greatest where the aquifers are hydraulically connected to surface-water sources, where pumping induces recharge from the stream or lake. In Oswego County, yields to wells from such deposits may provide 100 to $1,000 \mathrm{gal} / \mathrm{min}$. 


\section{GROUND-WATER CONDITIONS AND LEACHATE MOVEMENT AT SITE NEAR OSWEGO}

This waste-incinerator-facility site is a 46-acre area on the northeastern edge of the city of Oswego at the confluence of White Creek with Wine Creek, the latter of which flows $1 / 2 \mathrm{mi}$ north to Lake Ontario (fig. 1). Approximately 11,000 barrels of chemical wastes were abandoned at the site in 1977. A 1 ist of chemicals received by the facility for disposal is given in table 1 . Although the disposal facility was designed to receive liquid waste only; another 8,000 barrels of reportedly solid waste were received and then sent from this site to the landfill near Fulton for disposal in 1974.

\section{Table 1.--Chemical compounds received at chemical-waste site near Oswego, 1969-7? \\ [Data from Scrudato and others, 1980.]}

\section{Elements}

Lead

Arsenic

Cadmium

Bromine

Sulfur

Aluminum

Chlorine

Chromium

Copper

Iodine

Iron

Mercury

Nicke 1

Silicon

Inorganic compounds

Sodium hydroxide

Ammonium chloride
Organic compounds

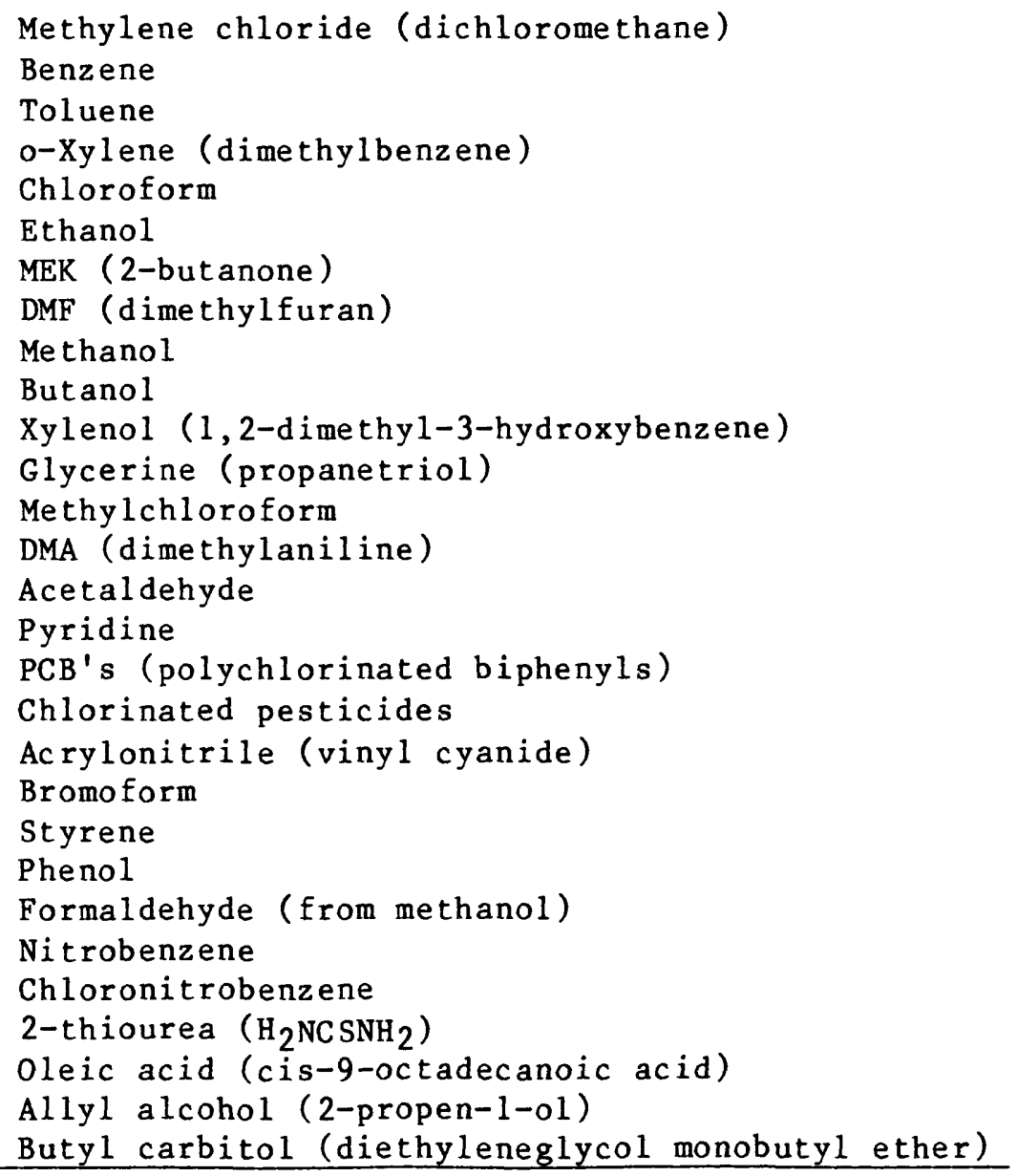

\section{Hydrogeology and Ground-Water Conditions}

The site lies on fill that is underlain by 2 to $14 \mathrm{ft}$ of glacial-lake deposits consisting of silt and clay on the west side, and sand and silt on the east, as shown on the surficial geologic map in figure 4. Ablation and 


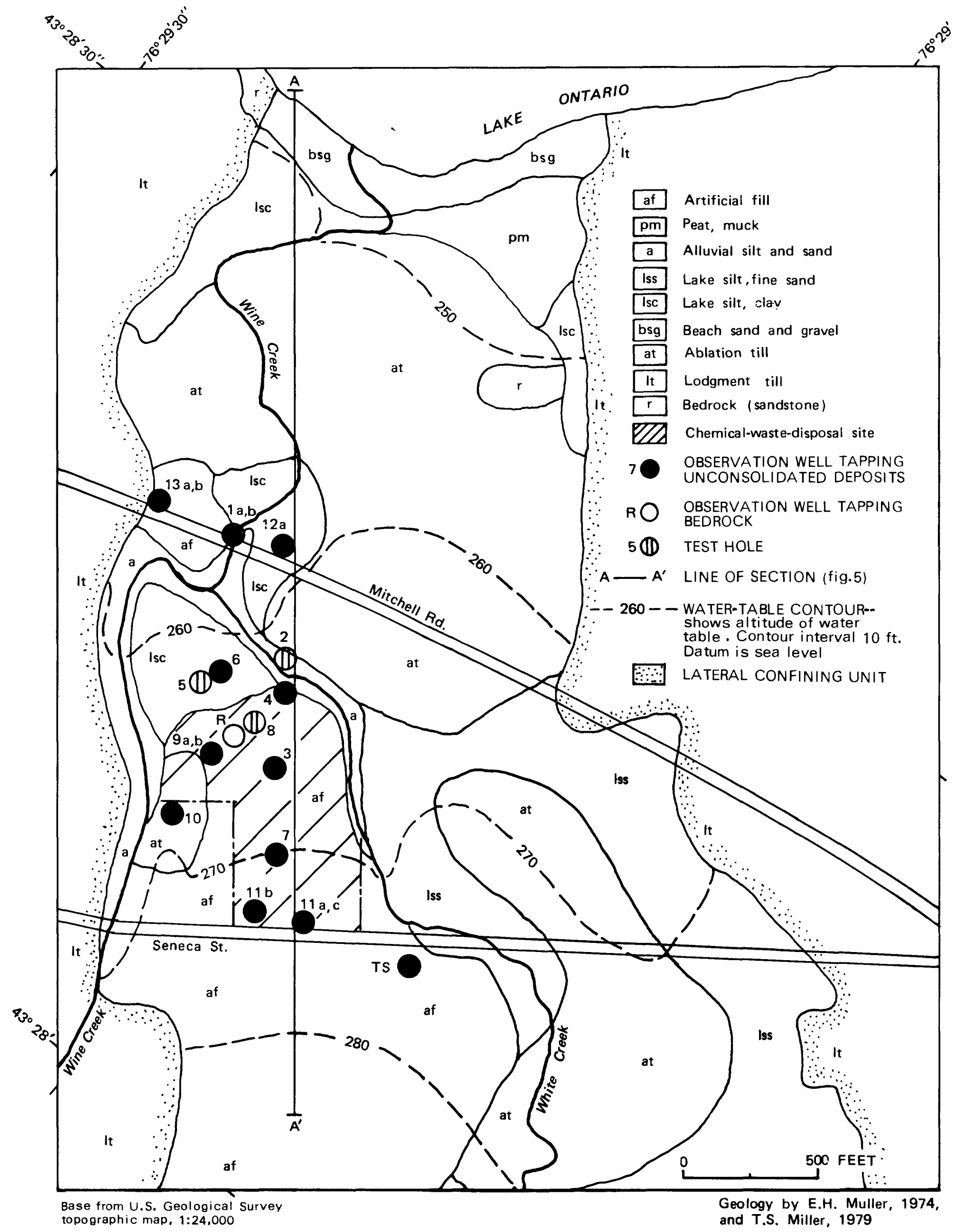

Figure 4.--Surficial geology, location of observation wells and test holes and 1980 water-table contours in vicinity of chemical-wastedisposal site near Oswego. (Location is shown in fig. 2.) 
lodgment tills underlie the lake deposits to depths as great as $40 \mathrm{ft}$. Bedrock underlies the till, which at places reaches depths of $40 \mathrm{ft}$ but in most places reaches only 20 to $25 \mathrm{ft}$, as indicated in the geologic section in figure 5. The glacial deposits at the site, whether lake silt, clay, fine sand, ablation till, or lodgment till, are relatively impermeable.

One well was installed southeast of the site to measure water levels and obtain water samples upgradient from the site (well TS, fig 4). Three pairs of wells ( $1 \mathrm{a}, 1 \mathrm{~b} ; 12 \mathrm{a}, 12 \mathrm{~b} ; 13 \mathrm{a}, 13 \mathrm{~b}$ in fig. 4) were installed downgradient from the site and on the opposite side of the two streams to detect contamination extending beyond the streams. Eleven wells $(3,4,6,7,9 a, 9 b, 10,11 a$, $11 \mathrm{~b}, 11 \mathrm{c}, \mathrm{R})$ were installed in the waste-storage area to measure water levels, define stratigraphy, and identify the extent of contaminant migration. Water levels were measured in all wells quarterly to obtain data for a water-table map (fig. 4) and plot the direction in which ground water moves. Records of wells and test holes are in table 8 (at end of report).

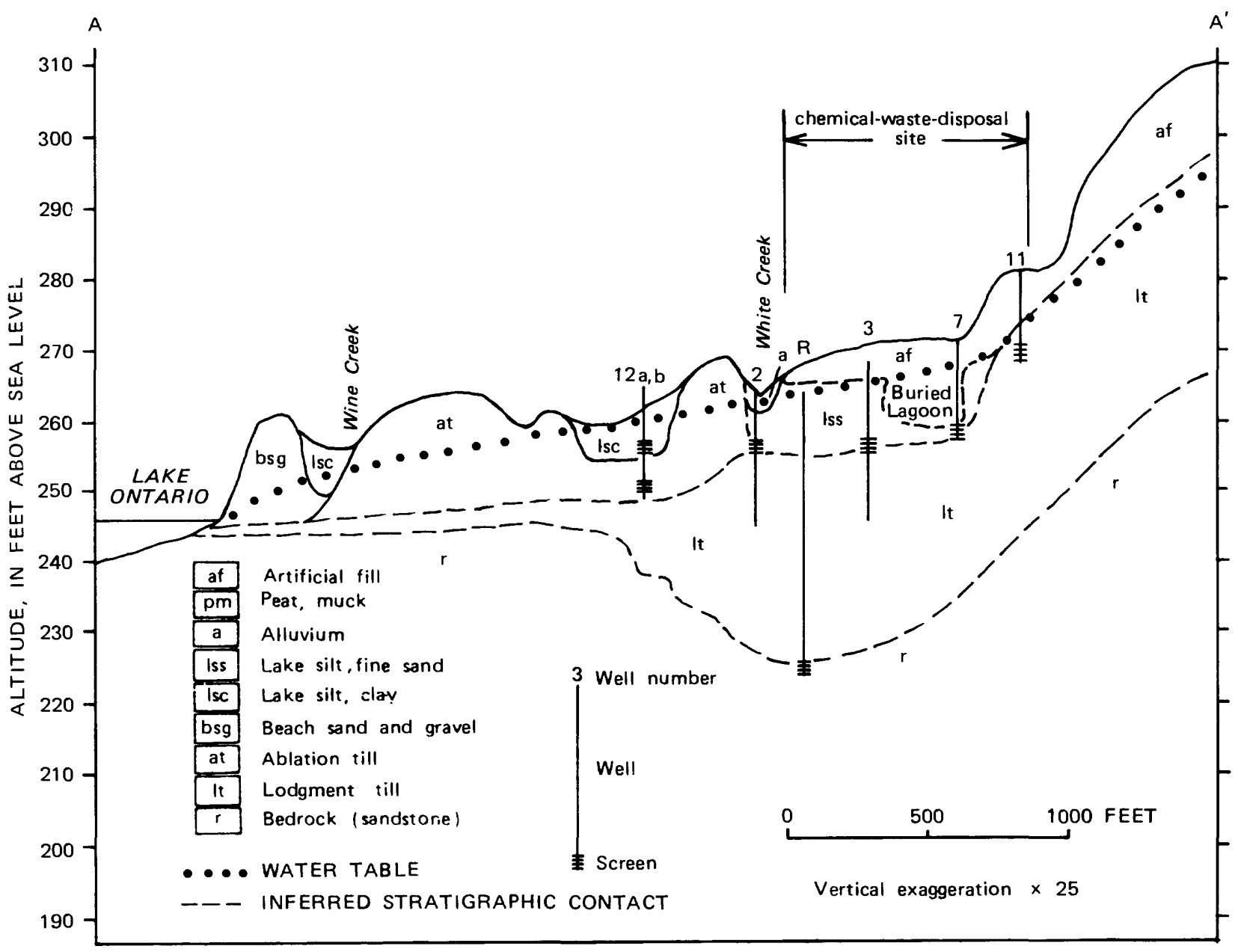

Figure 5.--Geologic section $A-A$ ' through vicinity of chemical-waste-disposal site near Oswego. (Location of section is shown in fig. 4.) 
Water levels in wells indicate that ground water moves northward toward Lake ontario (fig. 4). Water in the shallow ground-water system discharges directly to White Creek and Wine Creek; water in the deeper zones, particularly the upper fractured zone of the bedrock, may flow beneath Wine creek and ultimately seeps into Lake ontario.

\section{Permeability}

Brief pumping tests at four wells tapping till and bedrock indicate a relatively low permeability ranging from 0.06 to $7.5 \mathrm{ft} / \mathrm{d}$. The permeability values and calculated rates of ground-water flow through the various units are given in table 2. Values are based on a water-table gradient of $0.013 \mathrm{ft} / \mathrm{ft}$, determined from measured water levels and, for till, an estimated porosity of 0.30, which is typical of till (Freeze and Cherry, 1979). All flow rates are less than $1 \mathrm{ft} / \mathrm{d}$. The highest rate $(0.32 \mathrm{ft} / \mathrm{d})$ is in the upper bedrock zone. At this flow rate, ground water would take approximately 21 years to migrate the 2,500 ft from the site to Lake Ontario.

\section{Table 2.--Results of permeability tests at chemical waste-disposal site near oswego \\ [We11 locations are shown in $\mathrm{fig}$. 4.]}

\begin{tabular}{|c|c|c|c|c|c|}
\hline We11 no. & $\begin{array}{c}\text { Geologic } \\
\text { unit }\end{array}$ & $\begin{array}{c}\text { Type of } \\
\text { test }\end{array}$ & $\begin{array}{c}\text { Transmissivity } \\
(\mathrm{ft} 2 / \mathrm{d})\end{array}$ & $\begin{array}{c}\text { Pe rme ability } \\
(\mathrm{ft} / \mathrm{d})\end{array}$ & $\begin{array}{l}\text { Calculated } \\
\text { ground-water } \\
\text { flow rate } \\
(\mathrm{ft} / \mathrm{d})\end{array}$ \\
\hline $11 a$ & $\begin{array}{l}\text { Lodgment } \\
\text { till }\end{array}$ & $\begin{array}{l}\text { Slug } \\
\text { removal }\end{array}$ & 0.164 & 0.1 & 0.004 \\
\hline $13 a$ & $\begin{array}{l}\text { Till } \\
\text { and } \\
\text { s ands tone }\end{array}$ & $\begin{array}{l}\text { Slug } \\
\text { injection }\end{array}$ & 10.0 & 5.0 & .22 \\
\hline $12 b$ & $\begin{array}{l}\text { Ablation } \\
\text { till }\end{array}$ & $\begin{array}{l}\text { Slug } \\
\text { removal }\end{array}$ & 13.0 & 4.3 & .19 \\
\hline $\mathrm{R}$ & $\begin{array}{c}\text { Sands tone } \\
\text { bedrock }\end{array}$ & $\begin{array}{l}\text { Theis } \\
\text { recovery } 1\end{array}$ & 15.2 & 7.5 & .32 \\
\hline
\end{tabular}

1 Described in Lohman, 1979.

\section{Specific Conductance of Ground Water}

Specific conductance of water is roughly proportional to the concentration of dissolved salts in the water. Leachates normally contain higher concentrations of salts than native ground water; therefore, increased specific conductance may indicate presence of leachate. Specific conduct ance was measured in the field from samples collected at 15 wells $(1 \mathrm{a}, 1 \mathrm{~b}, 3,7,9 \mathrm{a}, 10,11 \mathrm{a}, 11 \mathrm{~b}$, $11 \mathrm{c}, 12 \mathrm{a}, 12 \mathrm{~b}, 13 \mathrm{a}, 13 \mathrm{~b}$, TS, R) quarterly throughout 1980 to discern whether leachate from the site had entered shallow and deep ground water. Lines of equal specific conductance at the site are shown in figure 6 .

Specific conduct ance of ground water in unconsolidated deposits within the site ranged from 1,000 to $5,000 \mathrm{Lmho} / \mathrm{cm}$, whereas conduct ance at we $11 \mathrm{~s}$ downgradient (north) ranged from 500 to $2,200 \mathrm{Lmho} / \mathrm{cm}$. 


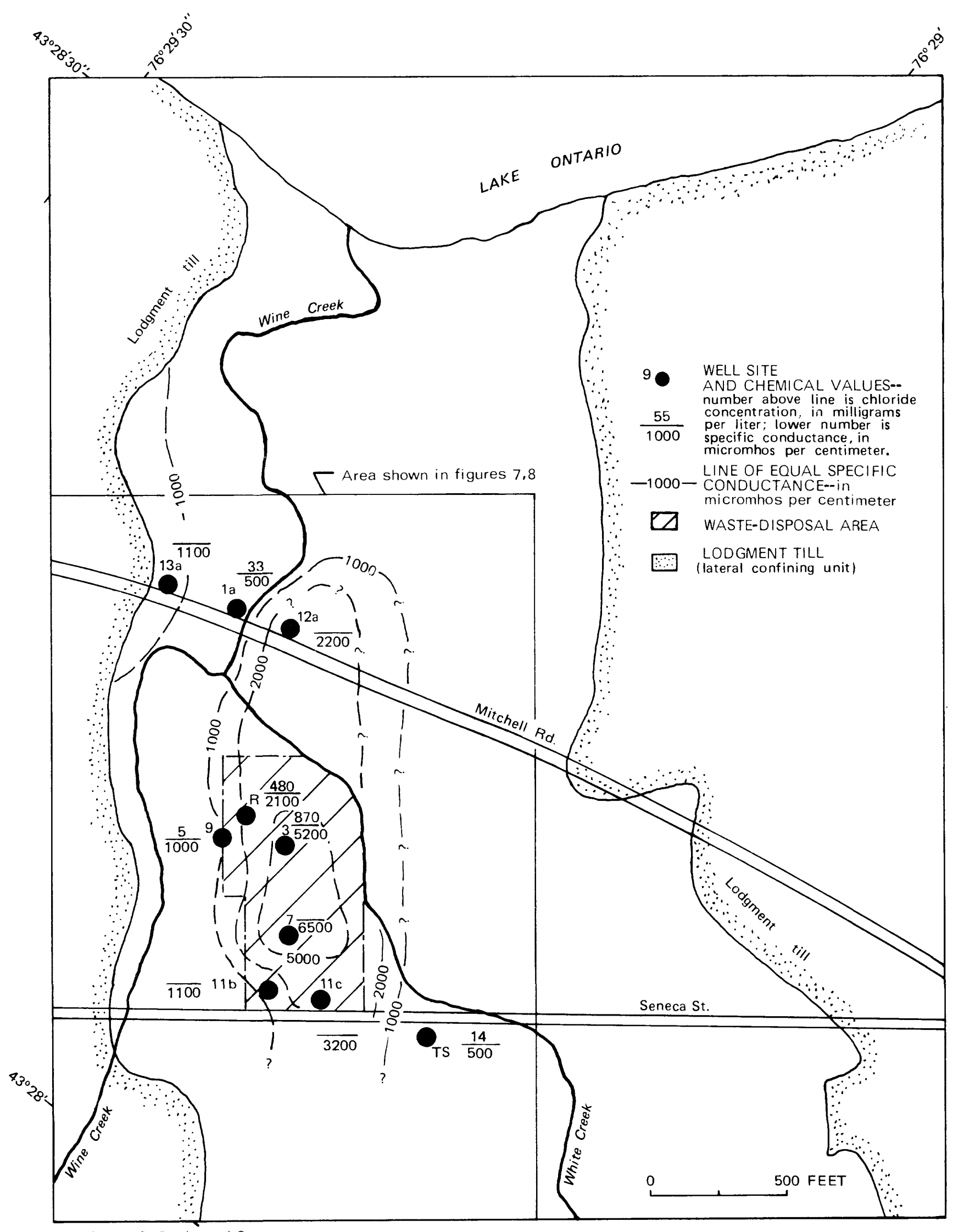

Base from U.S. Ge ological Survey topographic map. 1:24,000

Figure 6.--Specific conductance of ground water in vicinity of chemical-waste-disposal site near Oswego, August 1980. (Location is shown in fig. 2.) 
In August 1980, SURCO collected ground-water samples from seven wells (six in unconsolidated deposits and one in bedrock). Two samples--one from well TS and one from well 12a--were analyzed for chloride, bromide, arsenic, lead, mercury, and zinc. Samples from the other five wells $(1 \mathrm{a}, 3,7,9 \mathrm{a}$, and $\mathrm{R})$ were analyzed for the same constituents and for 28 volatile organic compounds on the Environmental Protection Agency list of 129 "priority pollutants" (tables 3 and 4 ).

Table 3.--Concentrations of selected halogens and trace metals in water from observation wells at the chemical-waste facility near Oswego.

[Analyses by U.S. Geological Survey, Atlanta, Ga. Numbers in parentheses indicate maximum recommended concentration for drinking water (U.S. Public Health Service, 1962). Underlined values exceed Federal drinking-water standards. Dashes indicate no standard exists. Well locations are shown in fig. 8.]

\begin{tabular}{|c|c|c|c|c|c|c|c|}
\hline \multirow{2}{*}{$\begin{array}{r}\text { We11 } \\
\text { no. }\end{array}$} & \multirow{2}{*}{$\begin{array}{l}\text { Type of } \\
\text { casing }\end{array}$} & \multirow{2}{*}{$\begin{array}{l}\text { Screen } \\
\text { depth } \\
\text { below } \\
\text { land sur- } \\
\text { face ( } f t)\end{array}$} & \multicolumn{2}{|c|}{$\begin{array}{l}\text { Halogens }(\mathrm{mg} / \mathrm{L}) \\
\text { total }\end{array}$} & \multicolumn{3}{|c|}{$\begin{array}{c}\text { Trace metals }(\mu \mathrm{g} / \mathrm{L}) \\
\text { total }\end{array}$} \\
\hline & & & $\begin{array}{l}\text { Chloride } \\
(250)\end{array}$ & $\begin{array}{c}\text { Bromide } \\
(--)\end{array}$ & $\begin{array}{l}\text { Arsenic } \\
(50)\end{array}$ & $\begin{array}{l}\text { Lead } \\
(50) \\
\end{array}$ & $\begin{array}{c}\text { Mercury } \\
(2)\end{array}$ \\
\hline \multicolumn{8}{|c|}{ Offsite wells } \\
\hline TS & S & 6 & 14 & 0.1 & 3 & 160 & 0.6 \\
\hline \multicolumn{8}{|c|}{ Onsite wells } \\
\hline 7 & $S$ & 14 & $\underline{6,500}$ & 0.9 & 24 & 3,800 & 4.5 \\
\hline 3 & $\mathbf{S}$ & 13 & 870 & 6.3 & 24 & 52 & 15 \\
\hline $9 a$ & $\mathrm{~S}$ & 16 & 51 & 0.6 & 3 & 8 & 0.1 \\
\hline $\mathrm{R}$ & $S$ & 41 & $\underline{480}$ & 1.1 & 20 & 5 & 0.2 \\
\hline $12 \mathrm{a}$ & $\mathbf{P}$ & 8 & $\overline{-1}$ & 0.3 & 6 & 92 & 0.2 \\
\hline $1 a$ & $S$ & 10 & 33 & 0.6 & 17 & $\underline{64}$ & $\underline{2.3}$ \\
\hline
\end{tabular}

1 S, steel; P, PVC.

Halogens.--High chloride concentration is a common indicator of leachate in areas of landfills and chemical-waste sites. Bromide was analyzed to discern whether the chloride was from the chemical waste or from upward-moving brackish water discharging from bedrock. (Bromide in natural waters is associated with brine and evaporite deposits and, like chlorides, is concentrated in sea water.) Brines generally contain more than $100 \mathrm{mg} / \mathrm{L}$ bromide; sea water contains $65 \mathrm{mg} / \mathrm{L}$ (Hem, 1970). Uncontaminated ground water generally contains only trace amounts. 
Bromide concentrations in shallow ground-water samples from the site contained from 0.1 to $6.3 \mathrm{mg} / \mathrm{L}$, with a median of $0.6 \mathrm{mg} / \mathrm{L}$ ( $t a b l e ~ 3)$. The higher concentration of $6.3 \mathrm{mg} / \mathrm{L}$ within the site at well 3 probably reflects contamination from the chemical wastes, and not brine from bedrock, because the bromide concentration at the bedrock well (R) was only $1.1 \mathrm{mg} / \mathrm{L}$.

Chloride concentrations in ground water in glacial deposits in oswego County are typically less than $100 \mathrm{mg} / \mathrm{L}$. Within the chemical-waste site near Os we go, however, chloride concentrations ranged from 14 to $6,500 \mathrm{mg} / \mathrm{L}$ (fig. $6)$. High concentrations within the site $(6,500,870$, and $480 \mathrm{mg} / \mathrm{L}$ at wells 7 , 3 , and $R$, respectively ( $t$ able 3 and $f i g .6$ ), suggest contamination. Concentrations at wells TS and $1 \mathrm{a}$, above and below the site, were 14 and $33 \mathrm{mg} / \mathrm{L}$, respectively (fig. 6).

Trace Metals.--Seven ground-water samples from test wells within and outside the site were analyzed for arsenic, lead, and mercury. Results are depicted in figure 7 and are given in table 3 along with the U.S. Public Health Service drinking-water standards.

Lead concentration exceeded the 50- $\mathrm{g} / \mathrm{L}$ limit both inside and outside the site in five of the seven wells sampled; these were well TS (upgradient from the site but downgradient from an old landfill), wells 7 and 3 (inside the site), and wells $12 \mathrm{a}$ and $1 \mathrm{a}$ (downgradient from the site). Mercury exceeded the 2- $\mu \mathrm{g} / \mathrm{L}$ limit in well 3 (inside the site) and in well la (downgradient). Arsenic was below the 50- $\mathrm{g} / \mathrm{L}$ limit at all seven wells.

Whether the relatively high concentrations of trace metals in some of the wells are derived entirely from this site is uncertain. For example, the high lead concentrations downgradient from the site in wells la and $12 \mathrm{a}$ may be due to auto emissions along Mitchell Road (fig. 7), overflow from the site's waste lagoon in 1974, or fly-ash fill material (which commonly contains heavy metals) under Mitchell Road. Well la is screened in fly ash that was used as road fill. The highest concentrations of trace metals were detected at wells within the confines of White and Wine Creeks and are probably derived from leaking barrels. Some trace metals may be contributed from the old landfill s outh of Seneca Street ( $\mathrm{fig} \cdot 4$ ).

Organic Compounds.--According to site records, more than 30 organic chemicals were handled at the disposal facility during 1968-77 (Scrudato and others, 1980). Ten of these have been classified among U.S. Envi ronmental protection Agency's "priority pollutants" (Keith and Telliard, 1979) for which the U.S. Geological Survey performed analyses. Samples from four test wells wi thin the site (table 4) contained nine of the 10 "priority pollutants"; these included benzene, chlorof orm, polychlorinated biphenyls (PCB's), phenol, 1,2 transdichloroethylene, me thylene chloride, toluene, 1,1,1 trichloroethane, and trichloroethylene. (The concentrations at several wells are shown in fig. 8.) In addition, some alcohols and carboxylic acids were detected in the four wells within the site. A list of the 18 "priority pollutants" analyzed for but not detected is given in table 5. No organic compounds were detected in well la on the other side of the streams. 


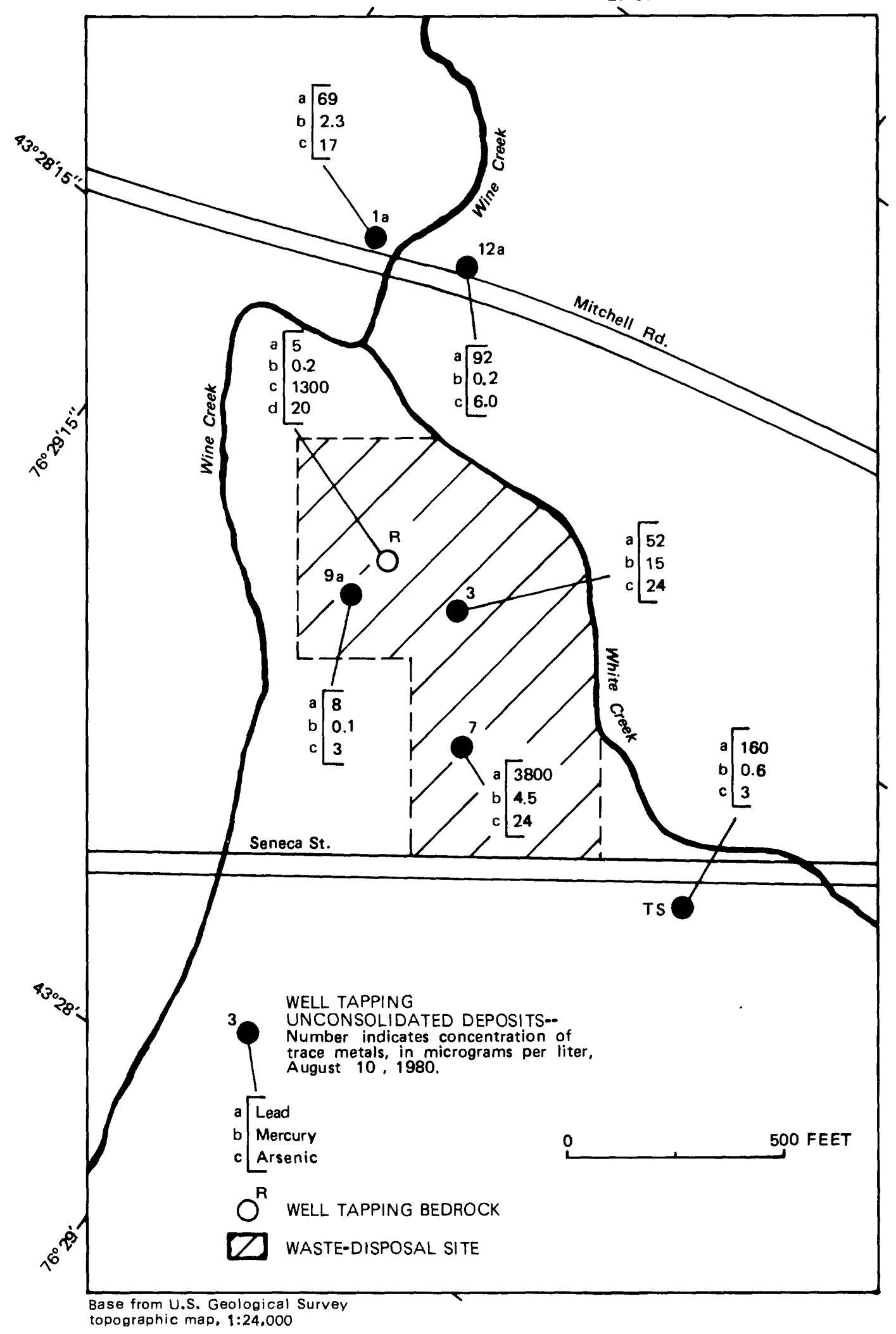

Figure 7.--Concentration of lead, mercury, and arsenic in ground water in vicinity of chemical-waste-disposal site near oswego, August 1980. (Analyses by U.S. Geological Survey, Atlanta, Ga.; additional data are given in table 3 . Location is shown in fig. 6.) 

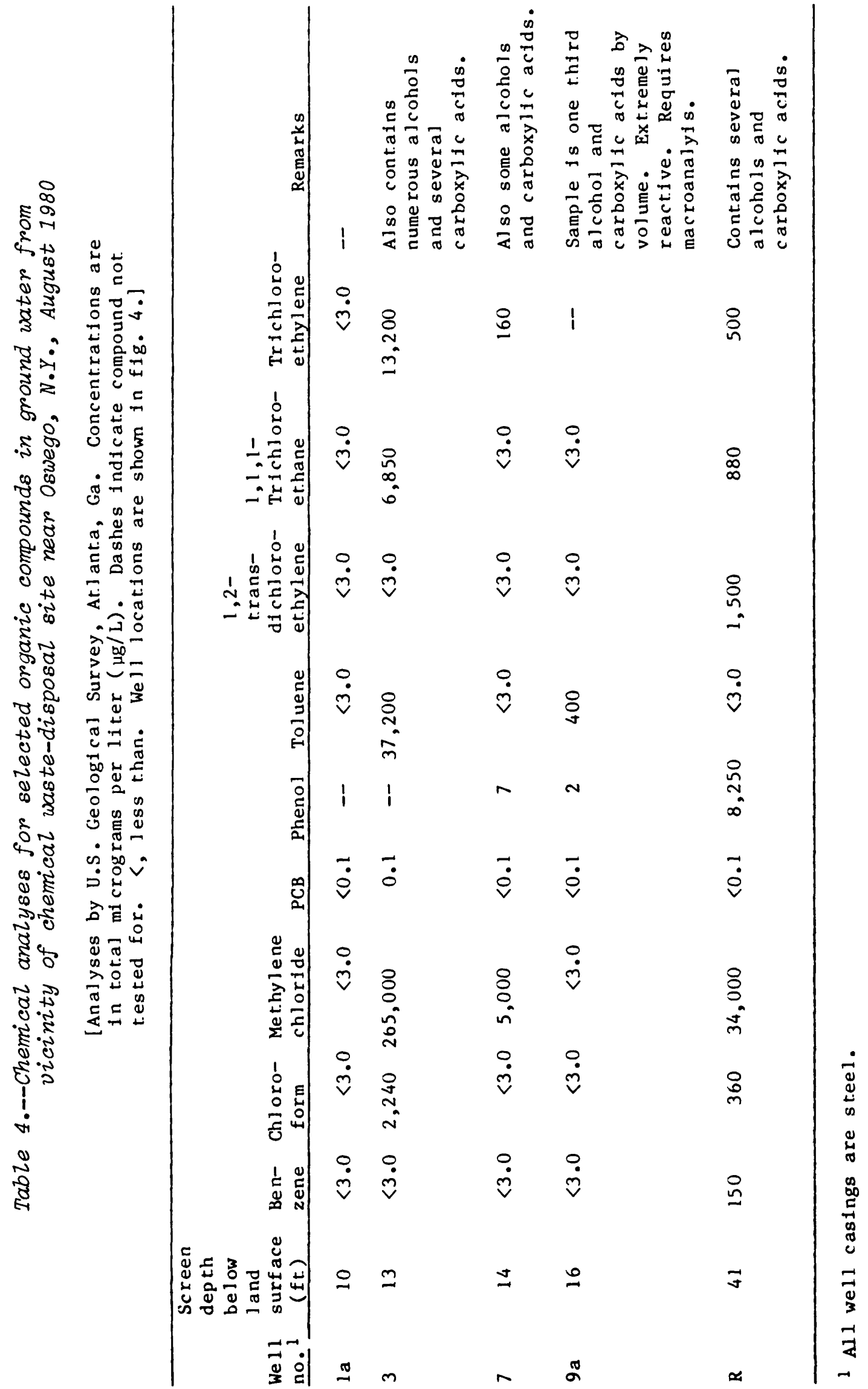


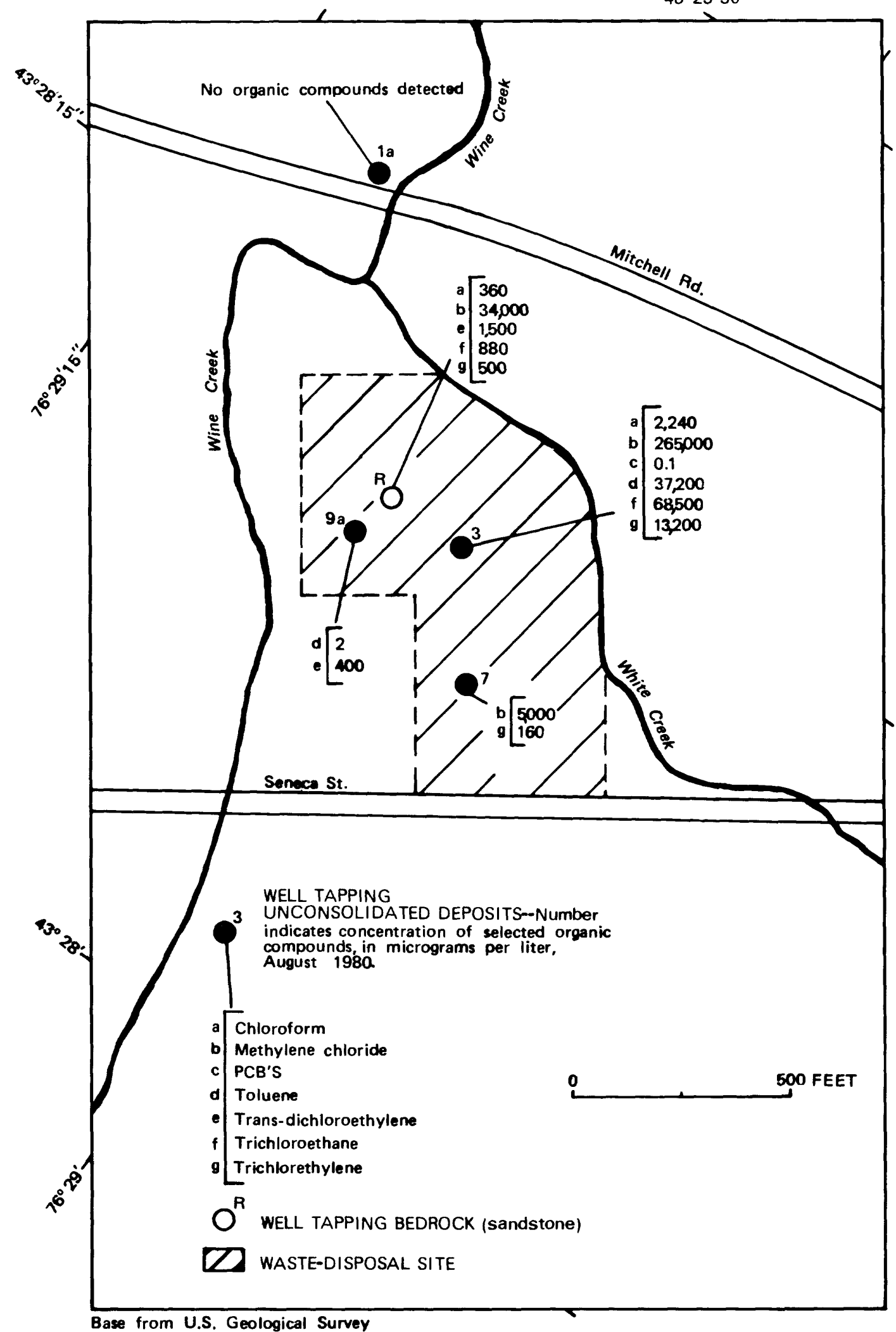

Base from U.S. Geological Survey

topographic map, 1:24.000

Figure 8.--Concentration of selected organic compounds in ground water in vicinity of chemical-waste-disposal site near oswego, August 1980. (Analyses by U.S. Geological Survey, Atlanta, Ga.; additional data are given in table 4. Location is shown in fig. 6.) 
Table 5.--Volatile organic "priority polzutants" tested for but not detected in ground-water samples from vicinity of chemical-waste-disposal site near Oswego, N.Y.

[Analyses by U.S. Geological Survey, Atlanta, Ga.]

\author{
Bromoform \\ Carbon tetrachloride \\ Chlorobenzene \\ Chlorodibromome thane \\ Chloroethane \\ Chlorodibromome thane \\ Ethylbenzene \\ Methylbromide \\ Tetrachloroe thylene
}
Trichlorofluoroe thane
Vinyl chloride
1,1-Dichloroe thane
1,1-Dichloroe thylene
1,2-Dichloroe thane
1,2-Dichloropropane
1,3-Dichloropropane
$1,1,2,2$-Tetrachloroe thane
2-Chloroethylvinyl ether

Water levels indicate that ground water within the site moves northward toward White Creek and Wine Creek (fig. 4). The four wells inside the site contained organic and some inorganic contaminants, including well $\mathrm{R}$, which taps bedrock, but the well downgradient and on the opposite side of White Creek (well 1a) did not contain organics (table 4). A conservative soluble contaminant would take about 3 years to move $500 \mathrm{ft}$ to reach well $1 \mathrm{a}$; insoluble and reactive contaminants may take longer. This estimate is made from the following formula, based on a median hydraulic conductivity of 4.32 $\mathrm{ft} / \mathrm{d}$, obtained from the permeability tests:

velocity $(\mathrm{ft} / \mathrm{d})=$ hydraulic conductivity $(\mathrm{ft} / \mathrm{d}) \mathrm{x}$ water-table gradient $(\mathrm{ft} / \mathrm{ft})$ porosity (dimensionless)

$$
\begin{aligned}
& =\frac{4.32 \times 13 / 1000}{0.30} \\
v & =0.19 \mathrm{ft} / \mathrm{d}
\end{aligned}
$$

Thus, time needed for a soluble contaminant to reach Mitchell Road would be

$$
\frac{500 \mathrm{ft}}{0.19}=2,632 \text { days, or } 7.2 \text { years. }
$$

The northward flow of ground water and the absence of organic compounds in well la (located north of White Creek and Wine Creek) suggest that leachate in the unconsolidated deposits discharges into White Creek and Wine Creek. Although the leachate would be diluted by streamflow, future analysis of stream samples should indicate whether leachate is entering these creeks. 
The well tapping bedrock within the site (well $\mathrm{R}$ ) was found to contain organic chemical contamination (table 4). More sampling of bedrock wells would be needed to determine whether contaminants have seeped into the bedrock flow system, were introduced during drilling, or are derived from the landfill upgradient (south of the site).

Results of the chemical analyses indicate that contamination within the site is derived from chemicals leaking from barrels and from spills of a former lagoon. Ground water moving from the abandoned landfill several hundred feet south of the site (fig. 4) may also be contributing some contaminants to the site. Ground water in the upper layer of unconsolidated deposits discharges to Wine Creek and White Creek and from there to Lake Ontario. Water from a well tapping the upper bedrock was found to contain several organic compounds, but otherwise, little data are available to indicate the depth to which contaminants have migrated.

\section{GROUND-WATER CONDITIONS AND LEACHATE MOVEMENT AT LANDFILL NEAR FULTON}

The second largest chemical-waste site in Oswego County is a sanitary landfill that occupies about 70 acres about 2 miles northeast of Fulton (fig. 1). The chemical-disposal facility near 0swego was designed to handle only 1 iquid waste; therefore, in 1974 , approximately 8,000 barrels of reportedly solid chemical wastes were sent to the landfill near Fulton for disposal. The barrels were reportedly buried at a depth of $20 \mathrm{ft}$.

\section{Hydrogeology and Ground-Water Conditions}

This landfill is on top of a north-south-trending drumlin that is covered by a veneer of sand and gravel. The drumlin forms a drainage divide between two watersheds, one that drains southeast to Bell Creek, the other northwest to Black Creek (fig. 9). Both creeks flow into the Oswego River, which in turn flows northwestward about $7 \mathrm{mi}$ to Lake Ontario (fig. 1). The landfill is adjacent to and upgradient from a sand and gravel aquifer on the south and east (fig. 10). Most of the landfill is in the catchment area of Bell Creek.

The eastern part of the landfill is excavated in permeable sand and gravel deposits 10 to $50 \mathrm{ft}$ thick that flank the east side of the drumlin. Only the lower part of the sand and gravel is saturated, however, as indicated in sections $A-A^{\prime}$ and $B-B^{\prime}$ (fig. 11). The central and western parts of the landfill are excavated into the top of the drumlin, which is composed of lodgment ti11. The 10-ft-thick layer of sand and gravel that covered the central and western part of the landfill was removed and mixed with till for use as cover material. The saturated sand and gravel adjacent to the landfill is less than $10 \mathrm{ft}$ thick but increases southward to a thickness of about $20 \mathrm{ft}$ (section C-C', fig, 11).

Water levels in observation wells indicate that the direction of groundwater flow in the sand and gravel (fig. 9) is controlled by the relatively impermeable till of the drumlin surface that forms the base of the sand and gravel aquifer. Precipitation that infiltrates the landfill generates 


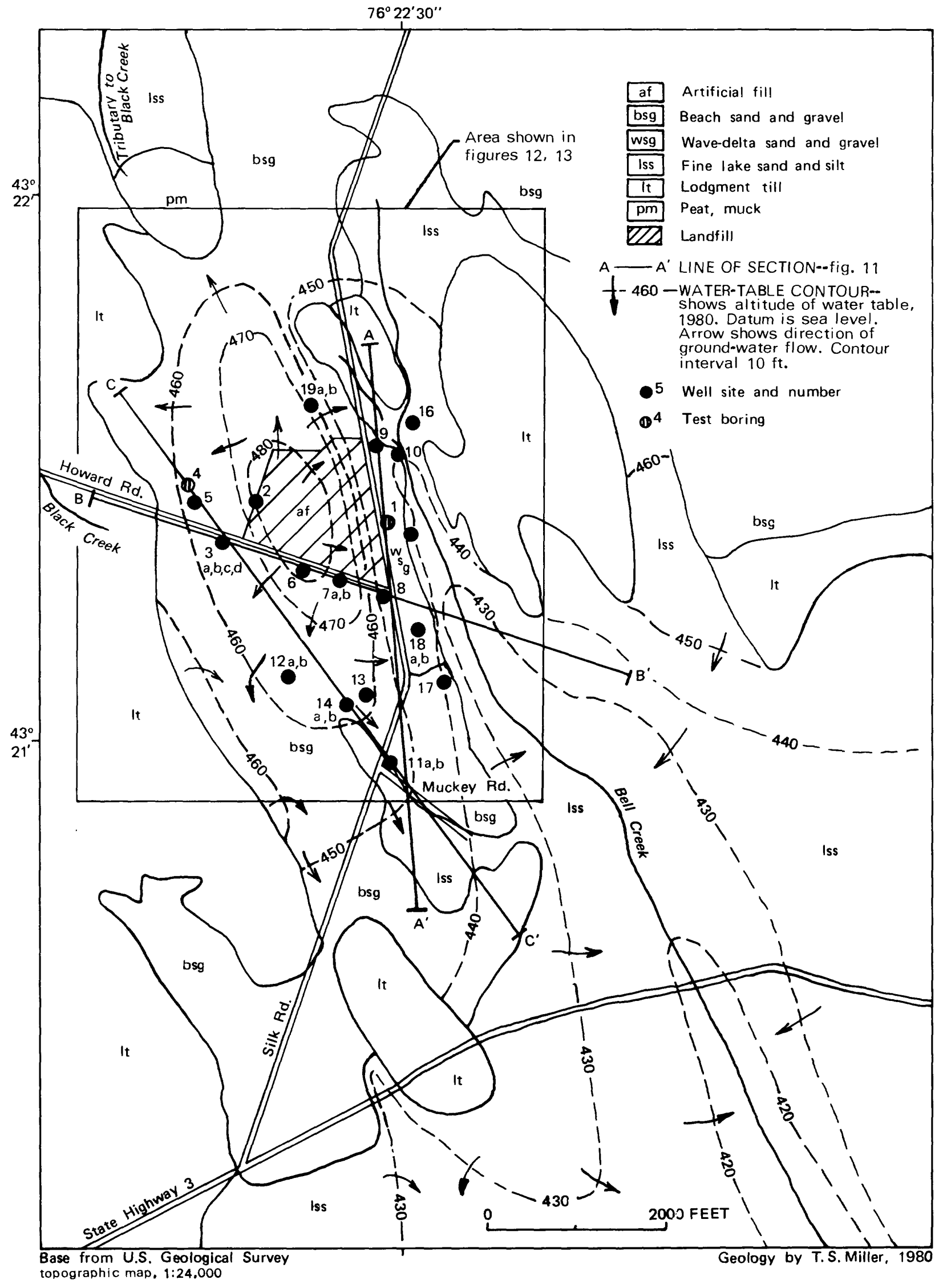

Figure 9.--Surficial geology, location of observation wells and test holes, and water-table contours in vicinity of landfill near Fulton 1980. (Location is shown in fig. 2.) 


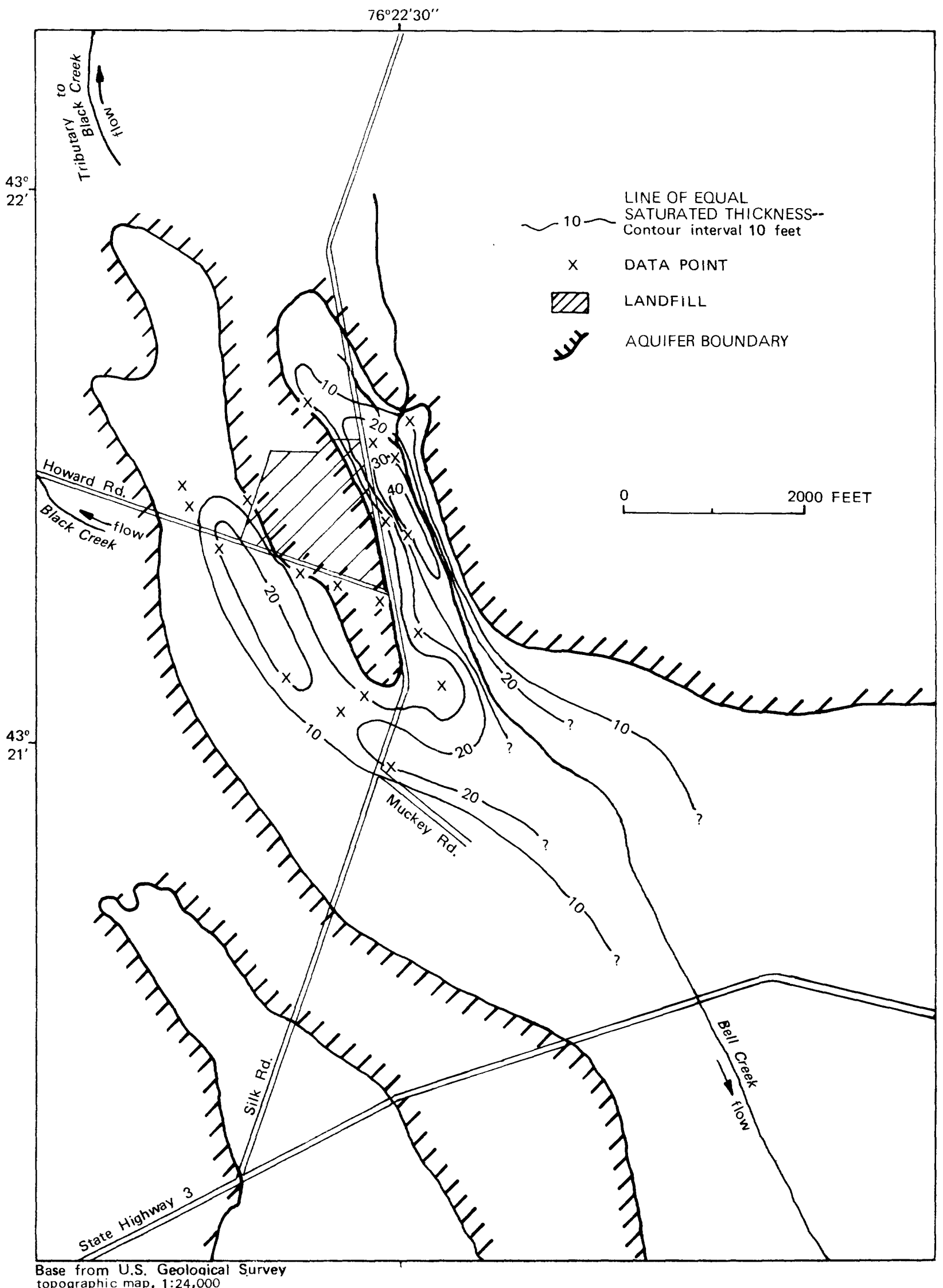

topographic map. 1:24.000

Figure 10.--Saturated thickness of sand and of sand and gravel aquifer in vicinity of landfill near Fulton. (Location is shown in fig. 2.)

21 

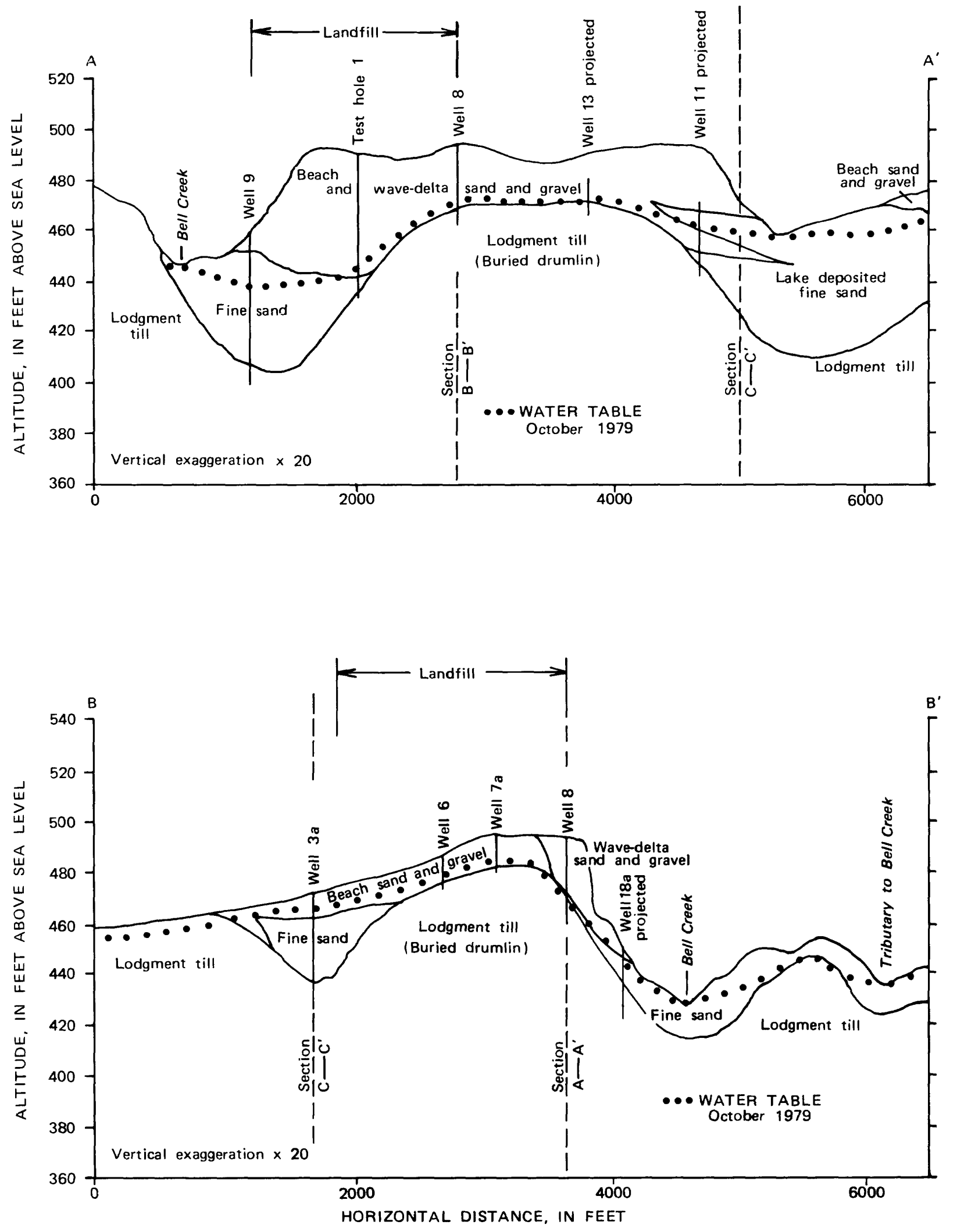

Figure 11.--Geologic section $A-A^{\prime}$ along Silk Road and $B-B^{\prime}$ along Howard Road in vicinity of landfill

near Fulton. (Locations are shown in fig. 9.) 


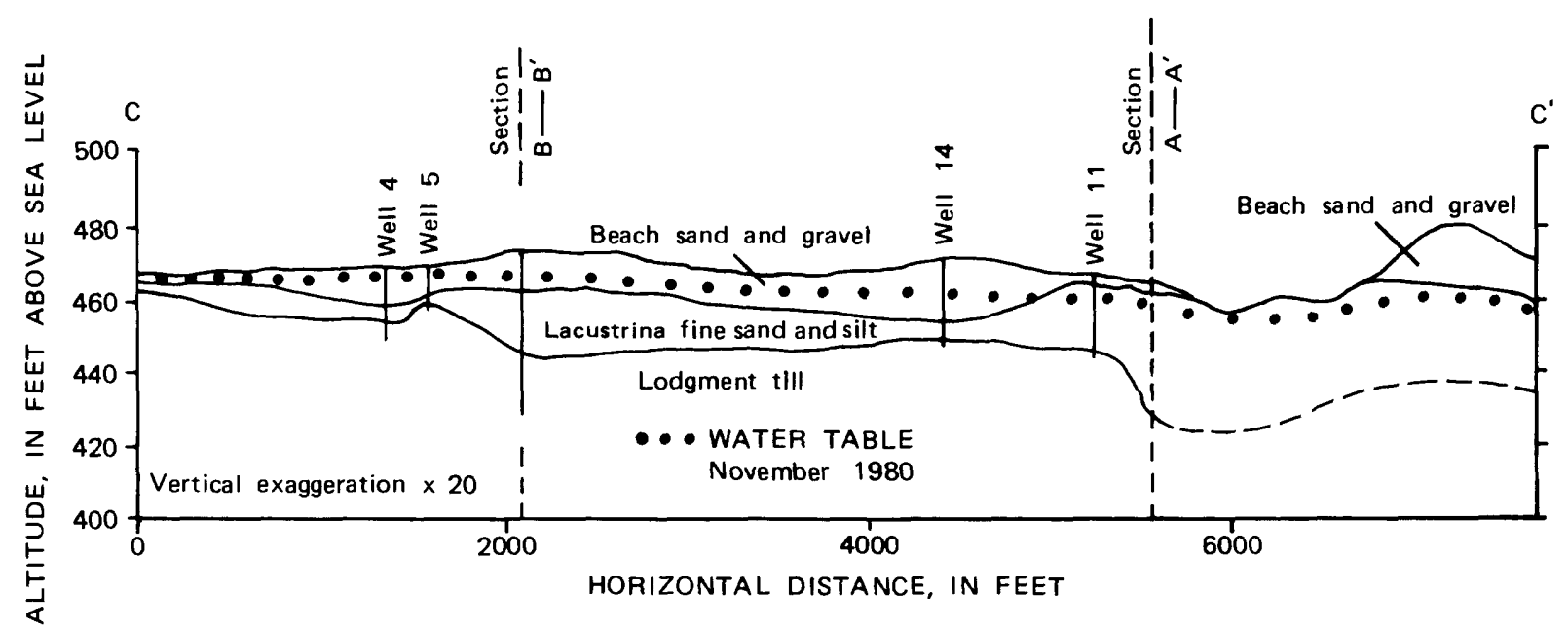

Figure 11 (continued).--Geologic section $C^{\prime} C^{\prime}$ south of Iandfill near Fulton. (Location of section is shown in fig. 9.)

leachate, which then moves radially away from the top of the drumlin and discharges partly to surface seeps along the edges of the landfill and partly as underflow down the buried flanks of the drumlin and into the sand and gravel aquifer, from which it either discharges eastward into Bell Creek or flows southwest into a tributary of the Bell Creek drainage system (fig. 9). It may also move downvalley (southward) as underflow beneath Bell Creek, and some may move northwestward through thin beach sand and gravel, but data on this area are scant. Some leachate generated within the landfill may infiltrate into the relatively impermeable till, but again, little information about the ground-water flow system in the drumlins is available. Records of wells and test holes are in table 9 (at end of report).

\section{Permeability}

The sand and gravel aquifer at this landfill (fig. 10) generally is more permeable than the deposits underlying the site near 0swego. A pumping test at well 14b (fig. 9), screened at 15 to $17 \mathrm{ft}$ in fine to coarse sand, indicated a transmissivity of $400 \mathrm{ft} 2 / \mathrm{s}$ and a permeability of $67 \mathrm{ft} / \mathrm{d}$. The saturated thickness of the aquifer is about $6 \mathrm{ft}$. A recovery test on well $3 \mathrm{c}$, screened from 33 to $35 \mathrm{ft}$ in very fine lacustrine sand, indicated a transmissivity of $1.5 \mathrm{ft} 2 / \mathrm{s}$. Permeability is estimated to be $0.2 \mathrm{ft} / \mathrm{d}$.

\section{Specif'ic conductance}

Maps showing the specific conductance of ground water during May 1980 and February 1981 are given in figures $12 \mathrm{~A}$ and 12B. Specific conductance of 


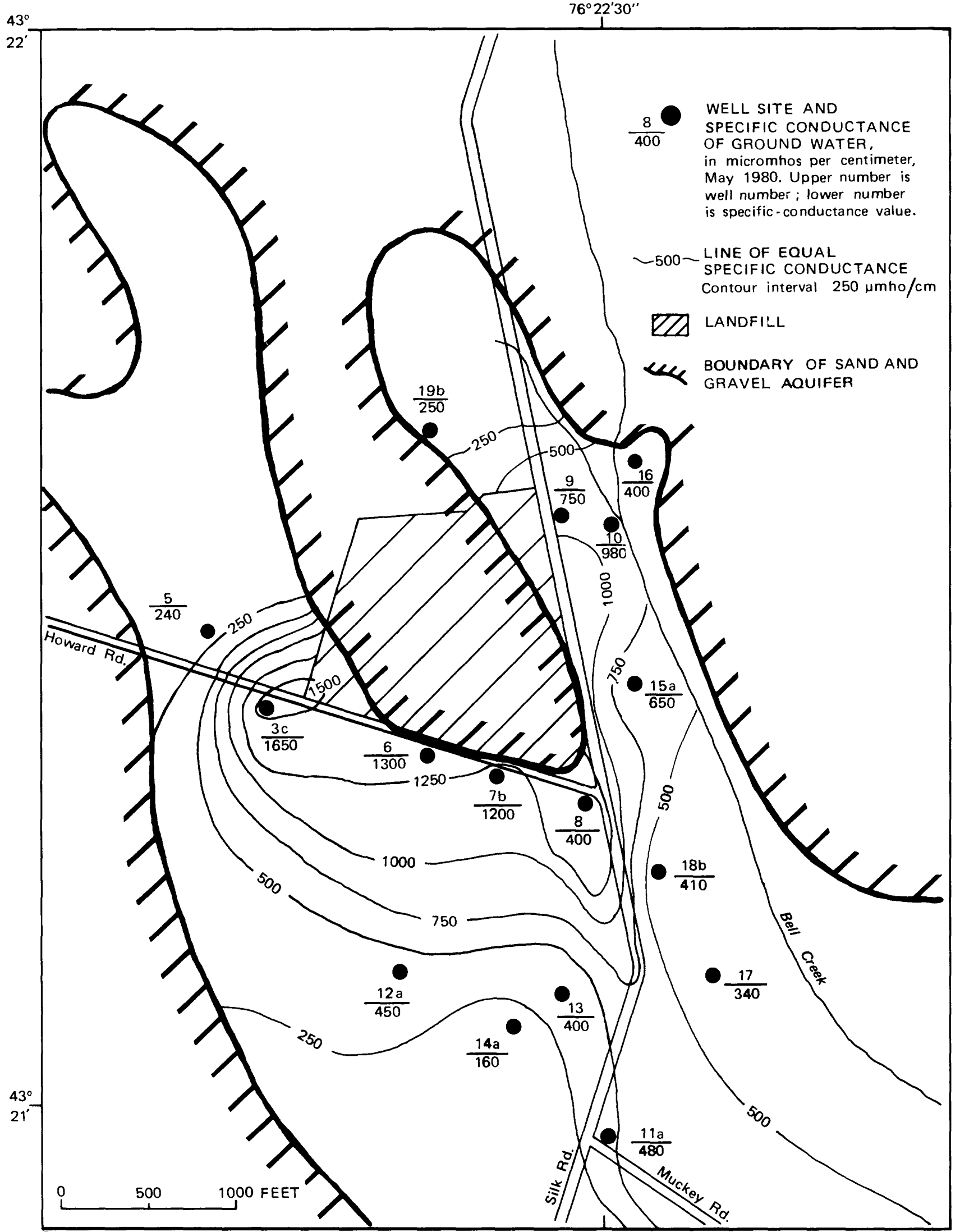

Base from U.S. Geological Survey topographic map, 1:24.000

Figure 12A.--Specific conductance of ground water in vicinity of landfill near Fulton, May 1980. (Location is shown in fig.9.) 


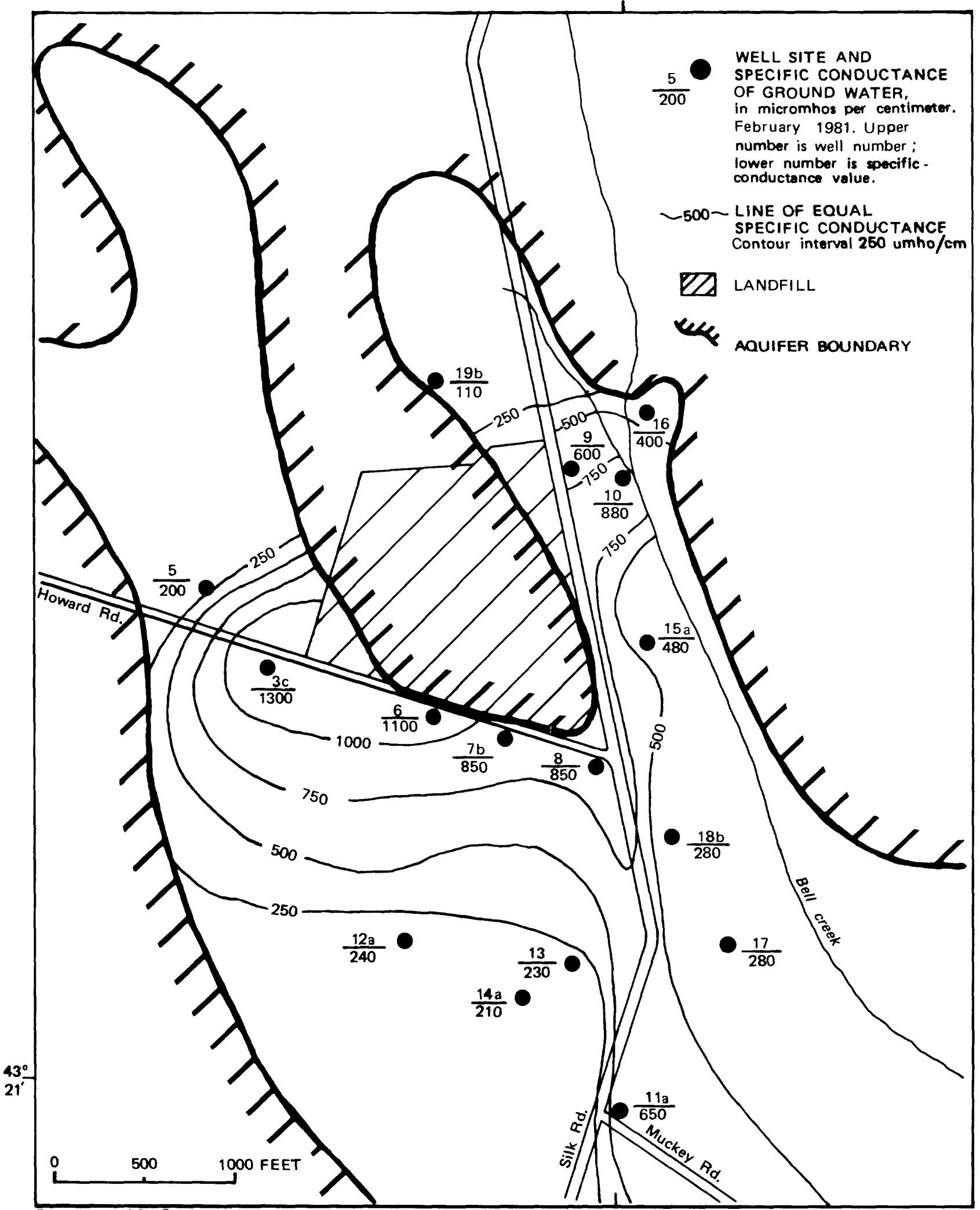

Base from U.S. Geological Survey

topographic map. $1: 24,000$

Figure 12B.--Specific conductance of ground water in vicinity of landfill near Fulton, February 1981. (Location is shown in fig. 9.) 
ground water at wells furthest from the landfill and least likely affected by it was less than $250 \mu \mathrm{mho} / \mathrm{cm}$. The specific conductance of water in wells along the south boundary of the landfill, along Howard Road (wells $3 a, 3 b, 3 c$, $3 \mathrm{~d}, 6,7$, and 8 in fig. 12), ranged from 850 to 1,650 umho, which indicates movement of leachate-enriched water southward from the landfill. Wells 9,8 , $10,15 \mathrm{a}$, and $15 \mathrm{~b}$, along the east margin of the landfill, ranged from 480 to $1,400 \mu \mathrm{mho} / \mathrm{cm}$, indicating some leachate movement eastward toward Bell Creek. Wells west and north of the landfill (wells 5 and $19 \mathrm{~b}$, respectively) had low specific-conductance values, which indicates little or no leachate movement to those areas.

Al1 specific-conductance values were higher in spring than winter, presumably because the water table was receiving little or no recharge in May 1980, which allowed the leachate to become more concentrated. February 1981 was a period of relatively high recharge from rainfall and an early snowmelt, which would have diluted the leachate and resulted in lower conductance values.

Road salting may contribute to the conductance plume along Silk Road, southeast of the landfill (figs. 12A and 12B), but the values elsewhere do not reflect the road patterns.

Outside the landfill area, precipitation that infiltrates land surface forms a layer of fresh water over the leachate plume. Leachate-rich water is slightly denser and therefore sinks to lower saturated zones. For example, wells $3 c$ and $3 d$, southwest of the landfill (fig. 9), revealed a vertical zoning within a leachate front in which denser leachate with a higher dissolved-solids concentration has moved below the lighter ambient ground water. Water in the deeper well ( $3 \mathrm{c}$, depth $34.5 \mathrm{ft}$ ) had a specific conductance of $1,300 \mu \mathrm{mho} / \mathrm{cm}$ on May 22,1980 , whereas water in the shallow well ( $3 \mathrm{~d}$, depth $10 \mathrm{ft}$ ) had a specific conductance of $500 \mu \mathrm{mho} / \mathrm{cm}$.

\section{Temperature}

Temperatures of leachate-enriched ground water are higher than those of ambient water as a result of the heat generated by decomposition of organic matter. This is evidenced by the tendency of vegetation at landfills to stay green longer and snow to melt faster than elsewhere. The distribution of ground-water temperature at the site on May 22, 1980, November 2, 1980, and February 26, 1981 is shown in figure 13. During May 22, 1980, relatively high temperatures were recorded at well 9 (east of landfill), well 8 (southeast of landfill), and well 3c (southwest of landfill). (See fig. 13A.) Ground-water temperatures in February 1981 (fig. 13C) show the same pattern, except that al1 temperatures were lower. In November 1980 ( $\mathrm{fig}$. 13B), ground-water temperatures within and southeast of the landf 111 exceeded $15.0^{\circ} \mathrm{C}$, whereas ground water from distant wells ranged from $10.5^{\circ}$ to $12.0^{\circ} \mathrm{C}$. The temperature contours in figure 13 suggest that some of the leachate is moving eastward, southeastward, and southwestward from the landfill. 


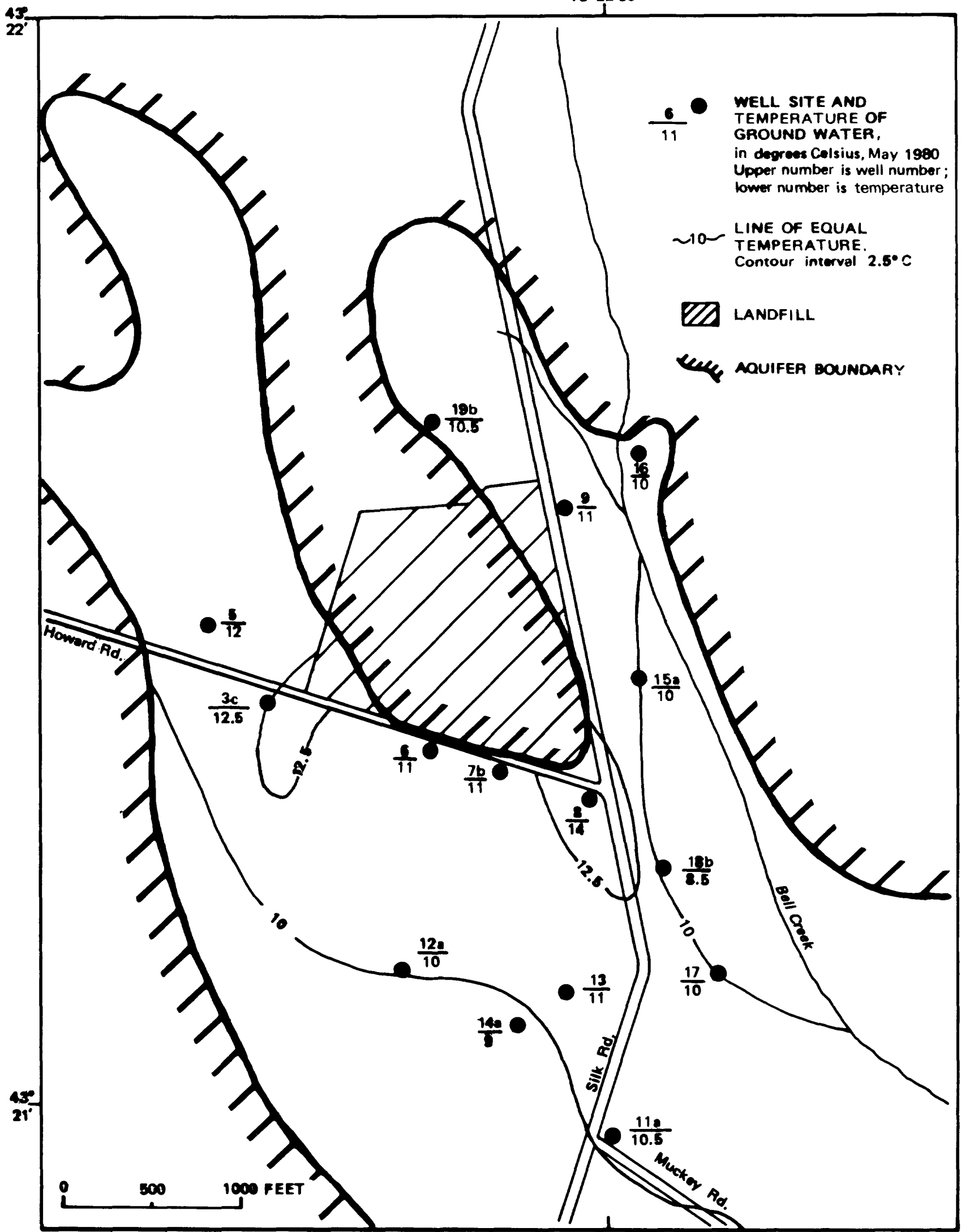

Bawe from U.S. Geolonical Surwey

topogrephic map, 1:24,000

Figure 13A.--Temperature of ground water in vicinity of landfill near Fulton, May 1980. (Location is shown in fig. 9.) 


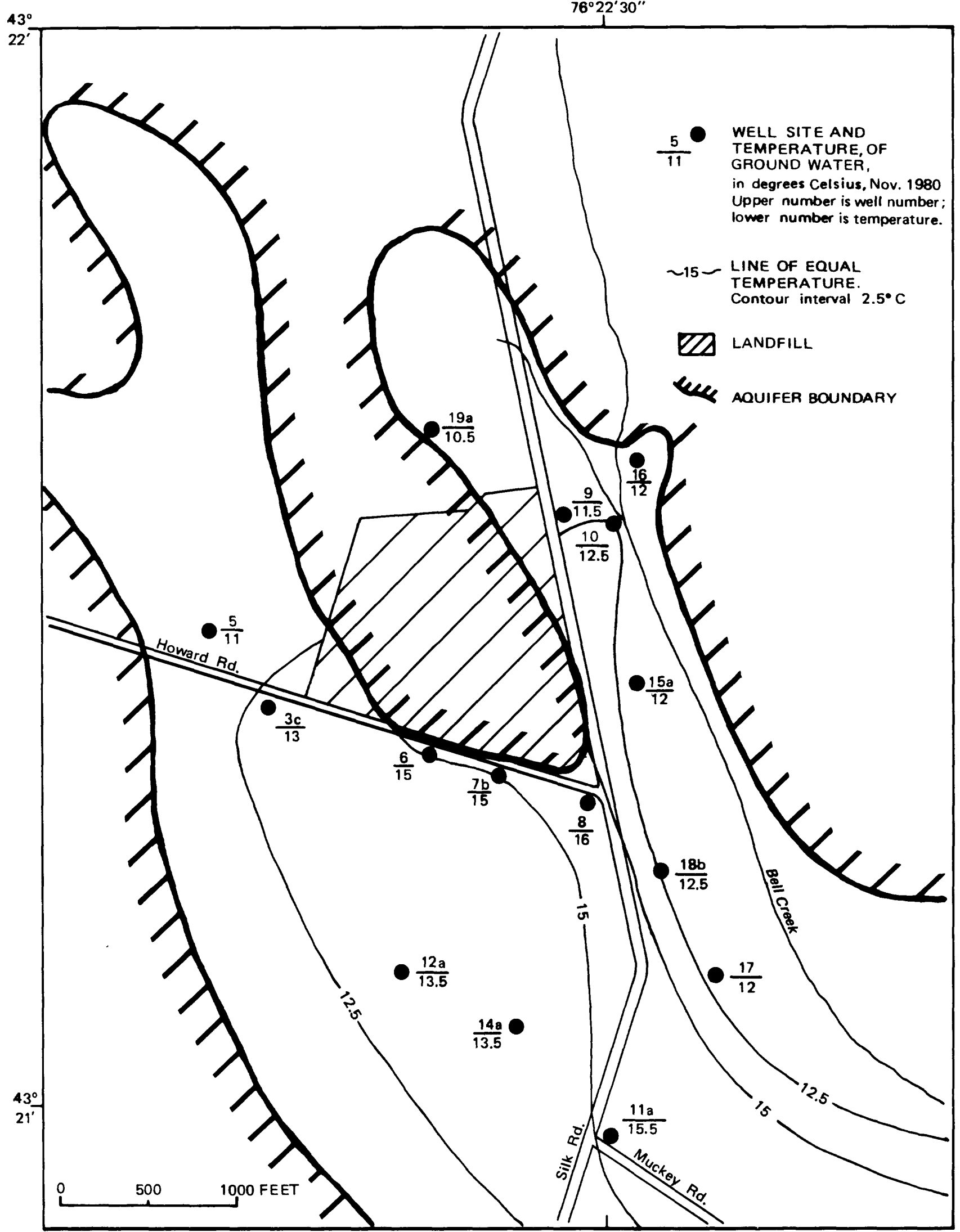

Base from U.S. Geologıcal Survey

topographic map, $1: 24,000$

Figure 13B.--Temperature of ground water in vicinity of landfill near Fulton, November 1980. (Location is shown in fig. 9.) 


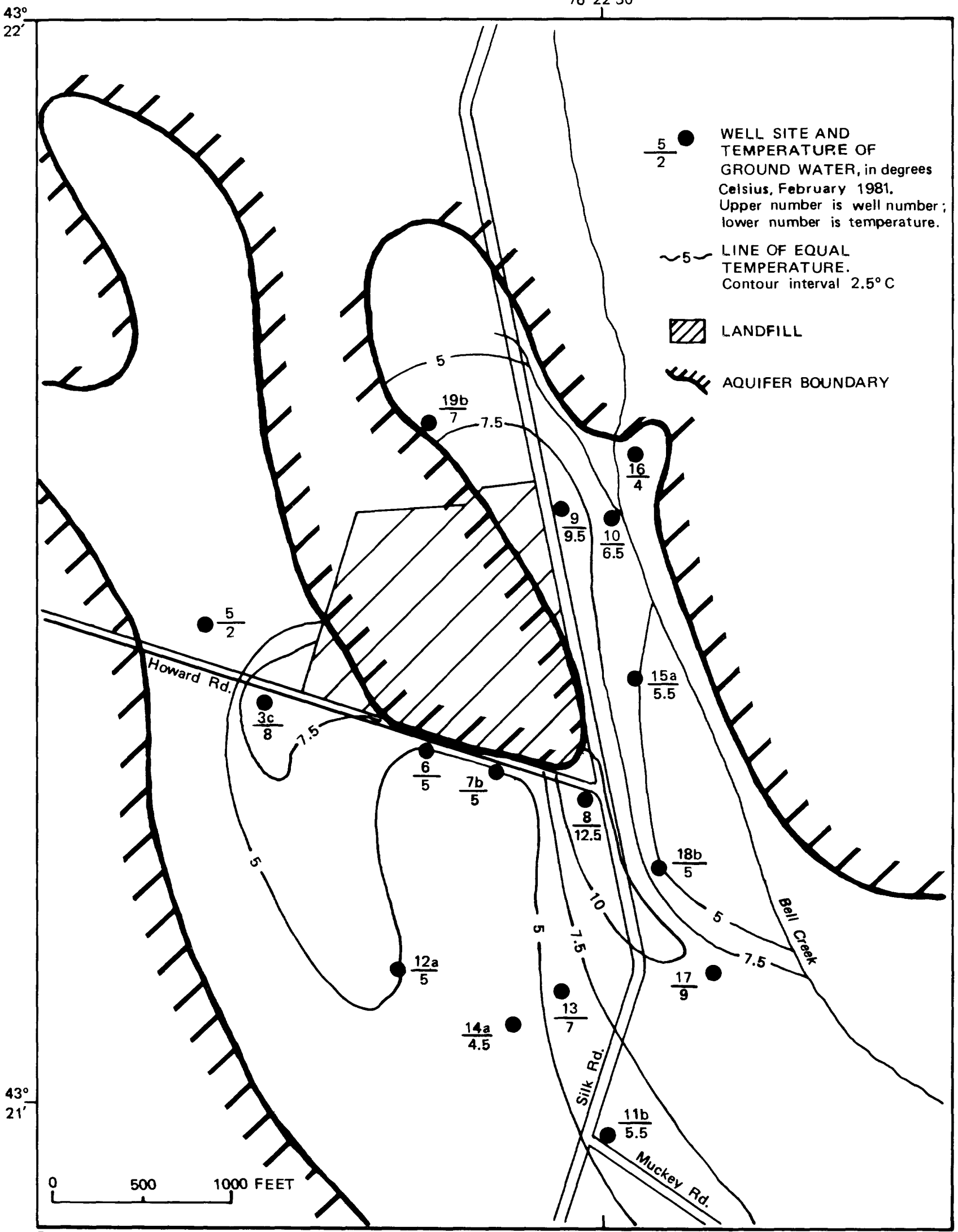

Base from U.S. Geological Survey topographic map, 1:24,000

Figure 13C.--Temperature of ground water in vicinity of landfill near Fulton, February 1981. (Location is shown in fig. 9.) 
Water samples were collected from seven wells (fig. 9), one within the site (we11 L) and six outside it (we1ls 3a, 10,1 1a, 11b,14b, and 15a) and analyzed for arsenic, lead, mercury, bromide, and chloride (table 6). Additional samples were collected from five of these wells, including the one within the site, and analyzed for selected organic compounds ( $t a b l e ~ 7)$.

Halogens.--Chloride and bromide concentrations were generally low outside the site, but inside the site the chloride concentration was $1,500 \mathrm{mg} / \mathrm{L}$ and that of bromide was $1.3 \mathrm{mg} / \mathrm{L}$.

Trace Metals.--Results of the trace-element analyses are given in table 6 . Arsenic concentrations exceeded the U.S. Public Health Service standard of $50 \mu \mathrm{g} / \mathrm{L}$ at we $11 \mathrm{10}$, which is in the path of eastward ground-water flow to Be 11 Creek (fig. 9). Lead concentrations exceeded the 50- $\mu$ g/L 1 imit in the well inside the landfill and in wells $3 a$ and 10 , south and east of the landfill, respectively. Mercury concentrations were less than the $2 \mu \mathrm{g} / \mathrm{L}$ standard in a 11 wells sampled.

In general, the analyses indicate little movement of heavy metals or of halogens outside the landfill, although lead and arsenic did exceed USPHS standards in two wells downgradient.

Table 6.--Concentrations of trace metals and halogens in ground water in vicinity of landfill near Fulton

[Analyses by U.S. Geological Survey, At lanta, Ga. Underlined values exceed U.S. Public Health Service standards, and numbers in parentheses indicate maximum recommended concentration. Well locations are shown in fig 9. NA, not analyzed.]

\begin{tabular}{|c|c|c|c|c|c|c|c|c|}
\hline \multirow[b]{2}{*}{$\begin{array}{c}\text { We } 11 \\
\text { no. }\end{array}$} & \multirow{2}{*}{$\begin{array}{l}\text { Type } \\
\text { of }\end{array}$} & \multirow[t]{2}{*}{$\begin{array}{c}\text { Screen } \\
\text { depth } \\
\text { below } \\
\text { land } \\
\text { surface }\end{array}$} & \multicolumn{4}{|c|}{ Trace metals $(\mu \mathrm{g} / \mathrm{L})$} & \multicolumn{2}{|c|}{ Halogens (mg/L) } \\
\hline & & & $\begin{array}{c}\text { Arsenic } \\
(50)\end{array}$ & $\begin{array}{l}\text { Lead } \\
(50)\end{array}$ & $\begin{array}{c}\text { Mercu ry } \\
\text { (2) }\end{array}$ & $\begin{array}{c}21 n c \\
(5,000)\end{array}$ & $\begin{array}{c}\text { Br omide } \\
\text { (2) }\end{array}$ & $\begin{array}{c}\text { Chloride } \\
(250)\end{array}$ \\
\hline
\end{tabular}

Leachate well (onsite)

$\begin{array}{llllllll}\mathrm{P} & 10^{3} & 39 & \underline{500} & 0.3 & \underline{7,100} & 1.3 & 1,500\end{array}$

Offsite wells

\begin{tabular}{|c|c|c|c|c|c|c|c|c|}
\hline $3 a$ & $\mathrm{~S}$ & 34 & 3 & $\underline{80}$ & .3 & NA & .9 & 120 \\
\hline 10 & $S$ & 12 & 61 & 180 & .3 & NA & .5 & 49 \\
\hline $1 \mathrm{la}$ & $\mathrm{P}$ & 18 & 4 & 11 & .2 & 20 & .1 & 85 \\
\hline $11 b$ & $S$ & 18 & 4 & 12 & .2 & $\mathrm{NA}$ & .3 & 81 \\
\hline $\begin{array}{l}14 b \\
15 a \\
\end{array}$ & $\begin{array}{l}\mathrm{S} \\
\mathrm{P} \\
\end{array}$ & $\begin{array}{l}17 \\
20 \\
\end{array}$ & $\begin{array}{l}3 \\
5 \\
\end{array}$ & $\begin{array}{l}14 \\
13 \\
\end{array}$ & $\begin{array}{r}.1 \\
.1 \\
\end{array}$ & $\begin{array}{l}\text { NA } \\
90 \\
\end{array}$ & $\begin{array}{l}0 \\
0 \\
\end{array}$ & $26^{.8}$ \\
\hline
\end{tabular}

1 S, steel; P, PVC.

2 No standard given.

3 Es timated value. 
Organic Compounds.--Samples from five wells we re sampled and analyzed for 28 of the 129 "priority pollutants" (table 7). Water from well L (fig. 9) inside the landfill contained toluene, trichloroethylene, methylene chloride, and PCB's in concentrations of $660,120,30,000$, and $1.4 \mathrm{\mu g} / \mathrm{L}$, respectively. The other samples contained zero or only traces or unde tectable concentrations of organic compounds, except for $250 \mu \mathrm{g} / \mathrm{L}$ of tolue ne at we11 $3 \mathrm{a}$, at the southwest corner of the landfill.

Table 7.--Concentrations of selected "priority" organic compounds in ground water in vicinity of landfill near Fulton

[Analyses by U.S. Geological Survey, Atlanda, Ga.

Concentrations are in micrograms per liter;

$<$, less than. Locations are shown in $\mathrm{fig} .10 .1$

\begin{tabular}{|c|c|c|c|c|c|c|c|c|}
\hline $\begin{array}{c}\text { Well } \\
\text { no. }\end{array}$ & $\begin{array}{l}\text { Type } \\
\text { of } \\
\text { cas- } \\
\text { ing } 1 \\
\end{array}$ & $\begin{array}{c}\text { Screen } \\
\text { depth } \\
\text { below } \\
\text { land } \\
\text { surface } \\
\text { (ft) } \\
\end{array}$ & Toluene & $\begin{array}{c}1,2 \\
\text { trans- } \\
\text { Dichloro- } \\
\text { ethylene }\end{array}$ & $\begin{array}{c}\text { Trichloro- } \\
\text { ethylene }\end{array}$ & $\begin{array}{l}\text { Methyl ene } \\
\text { chloride }\end{array}$ & PCB & Remarks \\
\hline \multicolumn{9}{|c|}{ Leachate well (onsite) } \\
\hline & $\mathbf{P}$ & 10 & 660 & $<3.0$ & 120 & 30,000 & 1.4 & $\begin{array}{l}\text { Contains many } \\
\text { carboxylic acids. }\end{array}$ \\
\hline \multicolumn{9}{|c|}{ Offsite wells } \\
\hline $3 a$ & $S$ & 34 & 250 & 7 & 3 & $<3.0$ & $<0.1$ & $\begin{array}{l}\text { Al so contains } \\
\text { several carboxylic } \\
\text { acids. }\end{array}$ \\
\hline 10 & $\mathrm{~S}$ & 12 & $<3.0$ & $<3.0$ & $<3.0$ & $<3.0$ & $<0.1$ & $\begin{array}{l}\text { Contains large } \\
\text { amount of molecular } \\
\text { sulfur. }\end{array}$ \\
\hline $14 b$ & $S$ & 17 & 2 & $<3.0$ & $<3.0$ & $<3.0$ & $<0.1$ & $\begin{array}{l}\text { Al so contains } \\
\text { several al cohols. }\end{array}$ \\
\hline $11 \mathrm{~b}$ & s & 18 & 2 & $<3.0$ & $<3.0$ & $<3.0$ & $<0.1$ & $\begin{array}{l}\text { Al so contains } \\
\text { several alcohols. }\end{array}$ \\
\hline
\end{tabular}

$1 \mathrm{~S}=$ steel, $\mathrm{P}=\mathrm{PVC}$

\section{Movement of Leachate}

The volume of leachate migrating from the landfill near Fulton each year may be substantial because of high permeability of sediments in hydraulic contact with the landfill along its southwestern, southern, and eastern boundaries. Because recharge is variable throughout the year, leachate is generated as periodic pulses. Leachate-rich water sinks to the bottom of the aquifer and moves downgradient, forming a leachate front or plume, the shape of which is determined by the aquifer's permeability. Where permeablity is uniform, the leachate front forms as an arc, broadening away from the site; 
but where the permeability is higher, the leachate extends forward as a narrow plume. The amount and concentration of leachate is a function of the area and saturated thickness of the refuse, whereas the distance leachate moves from the landfill is a function of time and ground-water velocity (Kimmel and Braids, 1980).

A soluble conservative compound would take a minimum of 28 months to trave1 2,400 ft from the landfill southward to the intersection of Muckey and Silk Roads (fig. 12A), as calculated from an estimated hydraulic conductivity of $67 \mathrm{ft} / \mathrm{d}$ for the fine to pebbly coarse sand that forms the aquifer, a porosity of 30 percent, and a water-table gradient of 0.0125 . (Insoluble and reactive contaminants could take appreciably longer.) From the formula for velocity $(v)$ :

$$
\begin{aligned}
v & =\frac{\text { hydraulic conductivity }(\mathrm{ft} / \mathrm{d}) \times \text { gradient }(\mathrm{ft} / \mathrm{ft})}{\text { porosity (dimensionless) }} \\
& =\frac{67 \times 0.0125}{0.30}=2.8 \mathrm{ft} / \mathrm{d}
\end{aligned}
$$

the velocity of ground-water movement is $2.8 \mathrm{ft} / \mathrm{d}$ or $1,022 \mathrm{ft} / \mathrm{yr}$.

\section{SUMMARY AND CONCLUSIONS}

Forty-five test holes and observation wells were installed at two major chemical-waste disposal sites in Oswego County--an abandoned chemical-wastedisposal facility near 0swego and a landfill northeast of Fulton--to evaluate ground-water conditions and the direction and extent of contamination emanating from the sites.

\section{Site Near Oswego}

This site contains 11,000 fifty-five-gallon barrels of chemical waste and occupies a north-south-trending interdrumlin swale. The barrels are on top of relatively impermeable unconsolidated glacial sediments less than $40 \mathrm{ft}$ thick.

Fine-grained glacial-1ake sediments overlie ablation and lodgment tills, which in turn overlie bedrock. The unconsolidated sediments have hydraulic conductivity values ranging from 0.06 to $4.3 \mathrm{ft} / \mathrm{d}$. Horizontal hydraulic conductivity of the upper part of the fractured bedrock is $7.5 \mathrm{ft} / \mathrm{d}$. Horizontal ground-water velocities range from $0.01 \mathrm{ft} / \mathrm{d}$ in the till to $0.75 \mathrm{ft} / \mathrm{d}$ in the bedrock. Ground water in the shallow unconsolidated deposits discharges to White Creek and Wine Creek. Deeper regional flow in bedrock is northward toward Lake ontario, $0.5 \mathrm{mi}$ to the north.

Le achate moves approximately $0.4 \mathrm{ft} / \mathrm{d}$ toward White Creek and Wine Creek, which join at the north end of the site and flow into Lake ontario. Specific conductance of ground water within the site was as high as 5,000 mho/cm but 
was less than 1,000 mho/cm outside the site. Lead concentrations in five of seven wells sampled exceeded the U.S. Public Health Service standard of $50 \mathrm{\mu g} / \mathrm{L}$. Lead concentrations at wells installed in unconsolidated deposits within the site ranged from $64 \mathrm{\mu g} / \mathrm{L}$ to 3,800 $\mathrm{\mu g} / \mathrm{L}$. Mercury concentrations exceeded the U.S. Public Health Service standard of $2 \mu \mathrm{g} / \mathrm{L}$ in three of the seven samples, including one downgradient of the site. Arsenic concentrations were below the $50-\mu g / L$ standard at all seven wells sampled.

Nine of the 28 organic compounds tested for and designated by the U.S. Environmental Protection Agency as "priority pollutants" were found in water from four wells within the site. These included benzene, chloroform, polychlorinated bi phenyls ( $P C B^{\prime} s$ ), phenol, trans-dichloroethylene, methylene chloride, toluene, trichlorethane, and trichloroethylene. The well downgradient from the site and across White Creek and Wine Creek contained none of the organic compounds.

More sampling would be needed between this site and the abandoned landfill several hundred feet upgradient (south) to determi ne what contaminants, if any, are coming from the latter. Leachate movement in fractured bedrock could be monitored if several test wells were installed in the 0.5 -mi strip between the site and Lake Ontario.

\section{Landfill Near Fulton}

This landfill contains about 8,000 fifty-five-gallon barrels of solid chemical waste. The landfill is on top of a drumlin, covered by a veneer of sand and gravel, that forms a drainage divide separating two watersheds--one that drains south toward Bell Creek, the other west-northwest toward Black Creek. Both creeks are tributary to the Oswego River. The landfill is mostly in the catchment area of Be 11 Creek.

The eastern part of the landfill is excavated in permeable sand and grave 1 deposits 10 to $50 \mathrm{ft}$ thick on the eastern side of the drumlin. The direction of ground-water flow through the sand and gravel is primarily east and southeast to Bell Creek. The direction of movement is controlled by the underlying surface of relatively impermeable lodgment till.

The western and central part of the landfill is excavated into the lodgment till that forms the drumlin. The overlying deposits of sand and gravel (10 ft or less) were removed before landfilling began and were used with till as cover material. South of and adjacent to the landfill, the saturated sand and gravel is less than $10 \mathrm{ft}$ thick but increases southward to $20 \mathrm{ft}$ thick. Ground-water temperatures and specific-conductance patterns indicate that leachate plumes are moving southwest, southeast, and east away from the landfill.

Analyses of trace metals in water at seven wells sampled indicate that arsenic exceeds the U.S. Public Health Service standard of $50 \mathrm{\mu g} / \mathrm{L}$ at a well 100 yards east of the landfill. Lead exceeded the $50 \mu \mathrm{g} / \mathrm{L} 1 \mathrm{imit}$ at the well. inside the landfill, at a well south of the site, and at a well east of the site. Mercury concentrations were less than the limit of $2 \mu \mathrm{g} / \mathrm{L}$ at all seven wells sampled. 
Analyses for organic compounds in water from the we 11 inside the landfill indicated significant concentrations of toluene $(660 \mu \mathrm{g} / \mathrm{L})$, trichloroethylene $(120 \mathrm{\mu g} / \mathrm{L})$, and methylene chloride $(30,000 \mathrm{\mu g} / \mathrm{L})$. Another we 11100 yards southwest of the landfill contained toluene $(250 \mu \mathrm{g} / \mathrm{L})$. The other three wells sampled contained insignificant amounts of the "priority pollutants" for which samples we re analyzed.

Specific-conductance and temperature measurements of ground water indicate leachate to be migrating from the landfill to the southwest, southeast, and east. At well $3 a$, at the southwest corner of the landfill, lead exceeded the U.S. Public Health Service standard, and toluene was detected.

\section{SELECTED REFERENCES}

Barton, Brown, Clyde and Loguidice, Consulting Engineers, 1967, 0swego County water supply study: New York State Department of Health, Contract CPWS-23, $111 \mathrm{p}$.

Freeze, R. A. and Cherry, J. A., 1979, Groundwater: Englewood Cliffs, N.J., Prentice-Ha11, Inc., 604 p.

Kantrowitz, I. H., 1970, Ground-water resources in the Eastern Oswego River basin, New York: New York State Department of Envi ronmental Conservation, Basin Planning Report ORB-2, $129 \mathrm{p}$.

Keith, L. H. and Telliard, W. A., 1979, Priority pollutants: Environmental Science and Technology, v. 13, no. 4, p. 416-423.

Kimmel, G. E. and Braids, O. C., 1980, Le achate plumes in ground water from Babylon and Is lips landfills, Long Island, New York: U.S. Geological Survey Professional Paper 1085, 38 p.

Lohman, S. W., 1979, Ground-water hydraulics: U.S. Geological Survey Prof essional Paper 708,70 p.

Miller, T. S., 1980, Surficial geology of Fult on quadrangle, Os wego County, New York: U.S. Geological Survey Water-Resources Investigations OpenFile Report 80-692, 1 sheet.

1980, Surficial geology of Oswe go East quadrangle, Oswego County, New York: U.S. Geological Survey Water-Resources Investigations Open-File Report 80-1209, 1 sheet.

1980, Surficial geology of Pennellville quadrangle, Oswego County, New York: U.S. Geological Survey Water-Resources Investigations, Open-File Report 80-411, 1 sheet.

1982, Geology and ground-water resources of Oswego County, New York: U.S. Geological Survey Water-Resources Investigations 81-60, 44 p. 


\section{SELECTED REFERENCES (continued)}

Miller, W. J., 1924, The geological history of New York State: New York State Museum Bulletin 255, 148 p.

Rickard, L. V. and Fisher, D. W., 1970, Geologic map of New York, Finger Lakes sheet: New York State Museum and Science Service, Map and Chart Series, no. 15, Finge $r$ Lakes sheet.

Scrudato, R. J. and others, 1980 , The potential for ground-water contamination by chemical waste leachate in Oswego County: Proceedings of the conference on toxic and hazardous chemicals, Central New York Regional Planning and Development Board, p. 87-105.

Scrudato, R. J. and Hinrichs, R. A., 1982, Migration of pollutants in ground water from the Oswego County landfill, Volney, New York, in Novitzki, R. P., ed., 1982, The impact of waste storage and disposal on groundwater resources: Ithaca, N.Y., Cornell University, Center for Environmental Research, 767 p.

Weist, W. G., Jr. and Giese, G. L., 1969, Water resources of the central New York region: State of New York Conservation Department, Water Resources Commission, Bulletin 64, 58 p.

U.S. Public Health Service, 1962, Public Health Service drinking water standards, 1962: U.S. Public He alth Service, Publication 956, 61 p. 


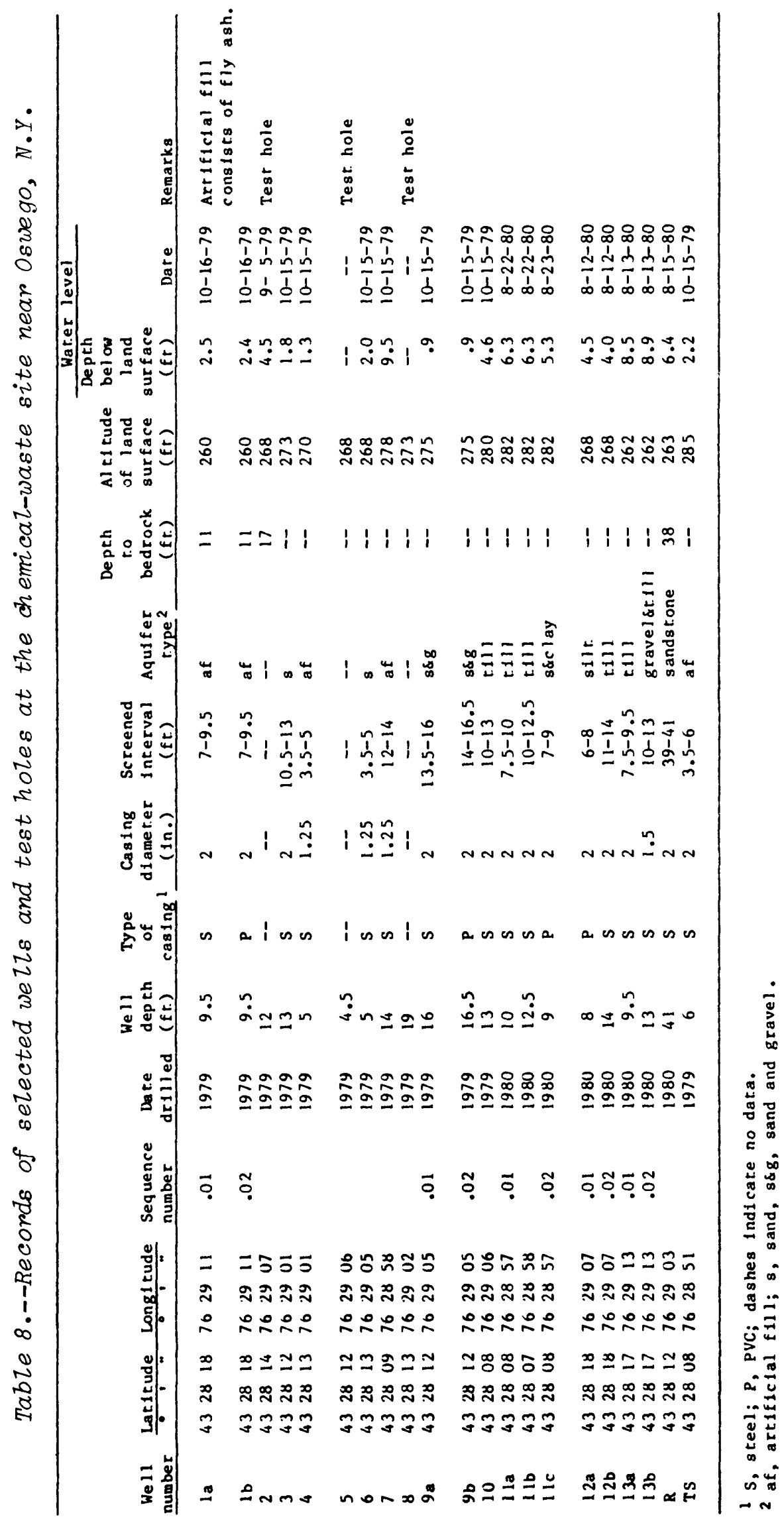




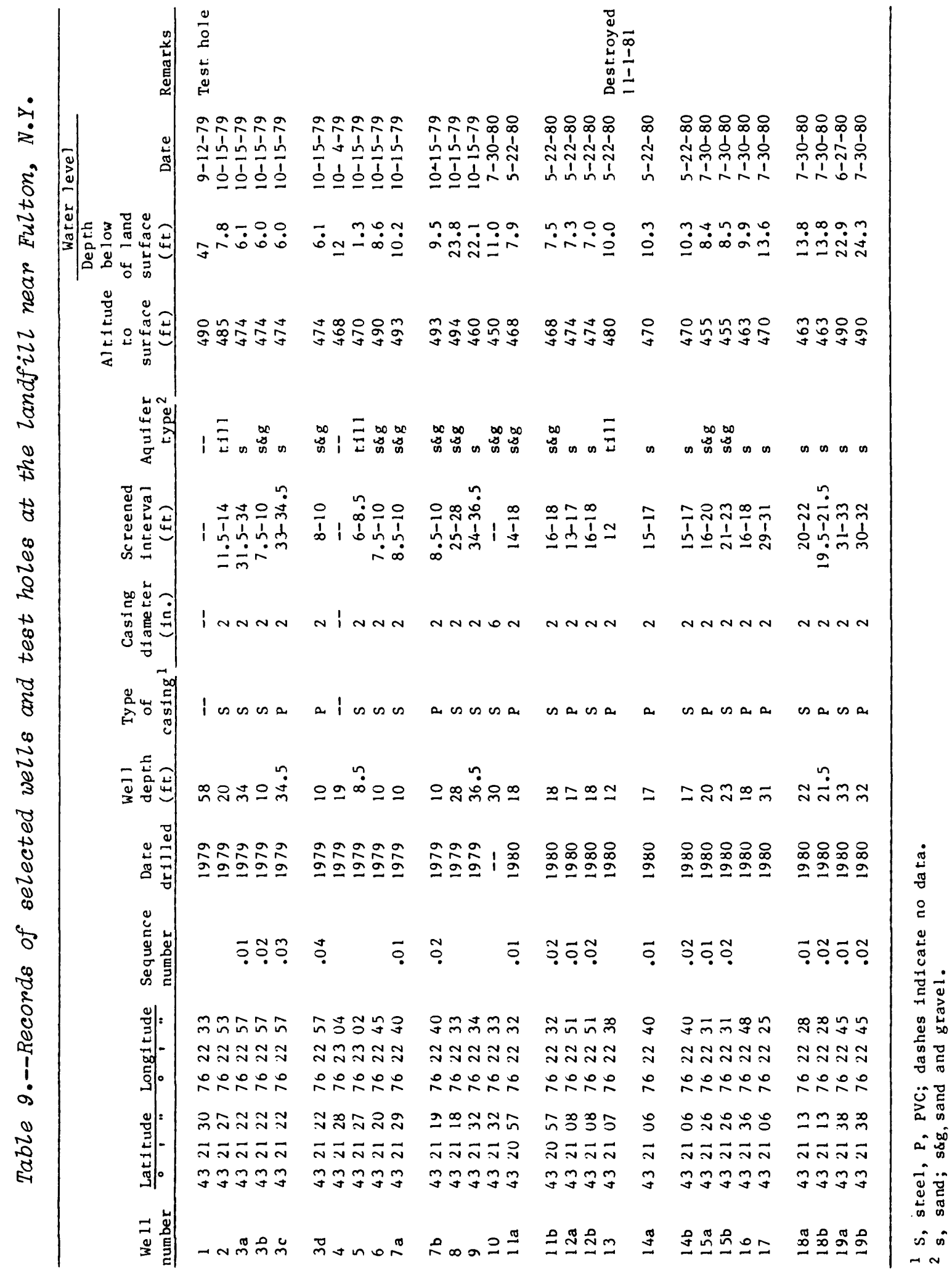

